\title{
Multidisciplinary studies supporting conservation programmes of two rare, endangered Limonium species from Spain
}

\author{
Sara González-Orenga • Ma Pilar Donat-Torres • Josep V. Llinares • \\ Albert Navarro • Francisco Collado $\cdot$ P. Pablo Ferrer-Gallego • \\ Emilio Laguna $\cdot$ Oscar Vicente $\cdot$ Monica Boscaiu
}

Received: 25 January 2021 / Accepted: 21 June 2021 / Published online: 13 July 2021

(C) The Author(s) 2021

\begin{abstract}
Background and aims Two local threatened endemics from Valencian salt marshes were analysed from a multidisciplinary perspective combining field studies with experiments performed under greenhousecontrolled conditions. The work aimed to investigate the habitat of the two species but also to explore their limits of tolerance to severe drought and salinity and the mechanisms behind their stress responses.

Methods The number of individuals in several populations, climatic conditions, soil characteristics and accompanying vegetation in the natural habitats
\end{abstract}

Communicated by Marius Grigore.

S. González-Orenga · J. V. Llinares · M. Boscaiu $(\bowtie)$ Mediterranean Agroforestry Institute (IAM, UPV), Universitat Politècnica de València, Camino de Vera 14, 46022 Valencia, Spain

e-mail: mobosnea@eaf.upv.es

S. González-Orenga · O. Vicente

Institute for the Conservation and Improvement of Valencian Agrodiversity (COMAV, UPV),

Universitat Politècnica de València, Camino de Vera 14, 46022 Valencia, Spain

M. Donat-Torres

Research Institute for Integrated Management of Coastal

Areas (IGIC), Universitat Politècnica de València, C/

Paranimf 1, 46730 Gandia, Valencia, Spain

A. Navarro · P. P. Ferrer-Gallego · E. Laguna

Centre for Forestry Research and Experimentation

(CIEF), CIEF-Wildlife Service, Generalitat were analysed in the field study. Plants obtained by seed germination were grown in the greenhouse and subjected to one month of water and salt stress treatments. Growth and biochemical parameters were analysed after the treatments were finalised.

Results No correlation between climatic parameters and the number of individuals censed of the two Limonium species could be established. Although $L$. dufourii was found in more saline soils in the natural habitats, under controlled greenhouse conditions, this species was more severely affected by salt treatment than L. albuferae, which is more susceptible to water stress. A common biochemical response was the increase of proline under all stress treatments, but mostly in water-stressed plants. Oxidative stress markers, MDA and $\mathrm{H}_{2} \mathrm{O}_{2}$, did not indicate significant differences between the treatments. The differences in

Valenciana, Avda Comarques del País Valencia, 114, 46930 Quart de Poblet, Valencia, Spain

F. Collado

Servici Devesa-Albufera, Vivers Municipals de El Saler, CV-500, km 8.5, 46012 Valencia, Spain 
the two species' responses to the two kinds of stress were correlated with the activation of the antioxidant enzymes, more pronounced in conditions of salt stress in L. albuferae and of water stress in $L$. dufourii.

Conclusions Although L. albuferae is found in sites with lower salinity in the natural habitats, the greenhouse experiment indicated that it tolerates higher concentrations of salt than $L$. dufouri, which is more resistant to drought. The two species efficiently mitigate oxidative stress by activation of antioxidant enzymes. The results obtained may be helpful for the conservation management of the two species: whereas salinity is not problematic, as the two species tolerated under controlled conditions salinities far beyond those in their natural environments, water scarcity may be a problem for L. albuferae, which proved to be more susceptible to water deficit.

Keywords Salt marshes - Salinity $\cdot$ Water stress . Endemics $\cdot$ Osmolyes $\cdot$ Antioxidants

\section{Introduction}

Coastal salt marshes represent ecosystems of great biodiversity and great ecological value (Gardner et al. 2015; Mitsch et al. 2015; Sutton-Grier and Sandifer 2019; Wolanski et al. 2009). In the region of Valencia (E Spain), they often appear as depressions integrated into dune systems, with the most saline areas located in the centre and the least saline at the edges of the salt marsh. The distribution of the different plant species in these saline areas is mainly determined by their relative tolerance to salinity, so that the plant communities are installed in concentric rings, depending on the salinity of the soil - although other factors, such as competition between species, can contribute significantly to the distribution of plants in the salt marsh (Grigore and Toma 2020). The complex of salt marshes developed in the Albufera Natural Park territory, located a few kilometres south of the city of Valencia, is of particular floristic and environmental interest (Ballester et al. 2003; Soria 2006). It shelters the unique populations of endemic Limonium albuferae, only found in this area (FerrerGallego et al. 2016), and Limonium dufourii, which is present also in a few other salt marshes outside the Natural Park (Aguilella et al. 2010).
The genus Limonium Mill. (Plumbaginaceae) is outstanding in the region of Valencia; of the 28 species present, 20 are Iberian endemics, and 12 grow exclusively in this region (Mateo and Crespo 2014). One of the most threatened endemic species of Limonium of the Valencian territory is L. dufourii (Girard) Kuntze (Aguilella et al. 2010). Historically, this species was more widely distributed along the coast and salt marshes in the region of Valencia, but today it is represented only by five natural populations restricted to small coastal areas in the provinces of Castellón (Torreblanca) and Valencia: Marjal dels Moros (with three populations), El Saler (Albufera Natural Park) and Cullera (Aguilella et al. 2010). Most of these populations have a very low number of individuals, and molecular analyses show that substantial genetic variability and differentiation exist within and between populations (Palacios and GonzálezCandelas 1997; Palacios et al. 1999). All the populations of $L$. dufourii are included in the Plant Microreserve network or Natural Parks (L'Albufera, Prat de Cabanes-Torreblanca) of the Valencian Community and also, additionally, in the European Union's Natura 2000 network of protected sites (as Site of Community Importance, SCI). The species is strictly protected in the Valencian region at the highest legal category, "In danger of extinction", included in the Valencian Catalogue of Threatened Plant Species (Aguilella et al. 2010).

Limonium albuferae P.P. Ferrer et al. is known only from a small site in the Albufera Natural Park, Racó de l'Olla (Ferrer-Gallego et al. 2016). At the beginning of 2020, 255 plants were counted, covering an area of about $160 \mathrm{~m}^{2}$. Therefore, this species will be included in the "In danger of extinction" category in the next edition of the Valencian Catalogue of Threatened Plant Species.

In a previous study on the two species ( $L$. dufourii and $L$. albuferae), based on metabolites profiling and the analysis of ion transport and accumulation, $L$. albuferae was found to be more salt-tolerant than $L$. dufourii, primarily due to its ability to accumulate fructose as a specific osmolyte (González-Orenga et al. 2019a). However, there is no information on the responses of the two species to drought, which can also affect their natural populations, especially in the changing climatic conditions of the global warming scenario, and neither on their ability to activate antioxidant mechanisms. Salinity and drought, like 
all other types of abiotic stress, are associated with an increase in reactive oxygen species (ROS) production, leading to cellular damage by oxidising unsaturated fatty acids in cell membranes, amino acid residues in proteins, and DNA molecules (Apel and Hirt 2004; Choudhary et al. 2019; Das and Roychoudhury 2014). Different biomarkers can be used for assessing the extent of the oxidative stress affecting the plants; for example, malondialdehyde (MDA), a lipid peroxidation product employed as a reliable oxidative stress marker in both animals and plants (Del Río et al. 1996) or hydrogen peroxide (Sofo et al. 2015). In response to increased ROS production, two main antioxidant categories are activated by plants. One is represented by non-enzymatic antioxidants, including phenolic compounds, especially the subclass of flavonoids, carotenoids, ascorbic acid, or glutathione. To the second category belong antioxidant enzymes, such as superoxide dismutase (SOD), catalase (CAT), ascorbate peroxidase (APX) (and other peroxidases), or glutathione reductase (GR), which are activated in conditions of oxidative stress (Dumanović et al. 2021; Ozgur et al. 2013).

This study has been performed from a multidisciplinary perspective, including an analysis of soil and vegetation in the natural environments of the two species, completed with climatic information, and an analysis of physiological and biochemical responses of plants grown under controlled stress conditions in the greenhouse. Several questions concerning the habitats occupied by the two species were posed. Are there any differences between the two species in the soil characteristics and composition of plant communities? Is the decline of the populations of $L$. dufourii related to reduced water availability or increased salinity enhanced by changes in the climatic conditions due to global warming? On the other hand, considering that water scarcity and increased soil salinity may be restrictive factors, the study aims to analyse the responses of plants to induced water stress and salinity under controlled greenhouse conditions, with a special emphasis on their antioxidant mechanisms not investigated before in these species. Based on our previous knowledge, the starting hypothesis was that the decline of some populations of $L$. dufourii is related to changes in its habitat and a lesser efficiency of stress tolerance mechanisms than in the recently described L. albuferae.

\section{Material and methods}

Area of study

The field study was conducted in several salt marshes from the Albufera Natural Park, located in the "Devesa de l'Albufera" (Valencia province, Spain). The area belongs to Wetlands of International Importance of the Ramsar Convention since 1990, and in 1991 it was declared as Special Protection Area under the EU Directive on the Conservation of Wild Birds (79/409/EEC). It also contains habitats and refuges of species included in the EU Habitats Directive (92/43/ EEC), and it is also classified within the Special Protection Areas in the Mediterranean, according to the Geneva Protocol (Soria 2006). The populations of the two Limonium species (L. dufourii and L. albuferae) are located in small salt marshes, locally named 'malladas', which are inter-dune depressions, often inundated during the winter period.

\section{Climatic analysis}

To establish a correlation with the evolution of the number of individuals in the censed populations, climate data were retrieved from SIAR, the Agroclimatic Information System for Irrigation (SIAR 2020) of the Spanish Ministry of Agriculture, Fisheries and Food. Data on the mean, maximum and minimum temperatures, rainfall and reference evapotranspiration (ETo) were collected for the past 19 years, on a monthly basis, from the agroclimatological station Benifaio (Valencia province), located $11 \mathrm{~km}$ from the area of study.

\section{Population censuses}

In each monitoring unit, censuses were made following the methodology of the Spanish Atlas and Red Data Book of Vascular Plants (Iriondo et al. 2003, 2009), adapted for the monitoring of endangered Valencian plant species by Navarro et al. (2010). Censuses were made from late July to late August, coinciding with the blooming period.

For $L$. dufourii, five natural population monitoring units were established, referred to as Devesa A (monitored since 2004), B (since 2005), C (since 2005) and D (since 2006); a new $\mathrm{E}$ unit has been established 
in 2020, as a result of the tracking made for the present work. Additionally, Devesa 1 and 2 units were established for two new artificial populations, planted in winter 2013-2014. Although the species vanished in monitoring units A, C and D in 2008-2009, their sites have been revisited every year, corroborating the absence of the species.

\section{Vegetation analysis}

Vegetation inventories were carried out in the areas where the populations of the two species are located in the study territory. The study was conducted according to the phytosociological method (BraunBlanquet 1964), adopting the International Code of Phytosociological Nomenclature (Weber et al. 2000). Braun-Blanquet values were transformed according to van der Maarel (1979). The nomenclature of the taxa follows EuroMed (2006) and the syntaxonomic nomenclature, according to Rivas-Martínez et al. (2001, 2002). Three measurements of soil electrical

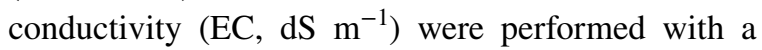
WET sensor (Delta Devices, Cambridge, England) at $10 \mathrm{~cm}$ depth in each inventory. The inventories were carried out mainly from mid-June to mid-November 2019.

\section{Soil characteristics}

Soil sampling was performed in July 2019. Samples were taken at $0-10 \mathrm{~cm}$ and $10-20 \mathrm{~cm}$ depth in the vicinity of specimens of the two species, from one salt marsh where the present unique population of L. albuferae is located, and from three salt marshes for $L$. dufourii. From each salt marsh, three soil samples were taken $(n=3)$. The samples were air-dried at room temperature and then crushed with a roller to break aggregates and passed through a $2-\mathrm{mm}$ sieve. Analyses were performed on fine soil (diameter $<2 \mathrm{~mm}$ ). Soil texture was analysed by the hydrometer method (Bouyoucos 1962). Organic matter was determined by the Walkley and Black method (1934) and carbonates by the technique of Bernard calcimeter (Loeppert and Suarez 1996). The following parameters were analysed in a saturation extract: $\mathrm{pH}$, electrical conductivity (EC), $\mathrm{Cl}^{-}, \mathrm{Na}^{+}, \mathrm{K}^{+}, \mathrm{Ca}^{2+}$, and $\mathrm{Mg}^{2+}$. A Crison $\mathrm{pH}-$ meter Basic 20 and a Crison conductivity-meter Basic 30 (Crison, Barcelona, Spain) were used to measure $\mathrm{pH}$ and $\mathrm{EC}$, respectively.
Sodium and potassium were quantified with a PFP7 flame photometer (Jenway Inc., Burlington, VT, USA), chlorides were measured in a MKII Chloride Analyzer 926 (Sherwood, Inc., Cambridge, UK). Divalent cations $\left(\mathrm{Ca}^{2+}\right.$ and $\left.\mathrm{Mg}^{2+}\right)$ were measured with an atomic absorption spectrometer SpectrA 220 (Varian, Inc., CA, USA).

Plant growth under greenhouse conditions

Seeds of $L$. albuferae and $L$. dufourii provided by the Centre for Forest Research and Experimentation of the Valencian Region (CIEF, Valencia) were sown on a mixture of commercial peat and vermiculite (3:1) and watered with Hoagland nutrient solution (Hoagland and Arnon1950). After three weeks, plantlets were transferred to individual $1 \mathrm{~L}$ pots placed in plastic trays, with five pots per tray, and watered one further week with Hoagland solution. One week later, when plants had achieved a sufficient size, stress treatments were started. Plants subjected to the salt treatments were watered with aqueous solutions of 200,400,600, and $800 \mathrm{mM} \mathrm{NaCl}$; those for the controls with distilled water, and those for the water stress treatment were not irrigated at all. Watering was performed by adding $1 \mathrm{~L}$ of the corresponding salt solution or water to each tray every five days. Five replicas (individual plants) were used per species and per treatment. All experiments were conducted in a controlled environment chamber in the greenhouse under the following conditions: long-day photoperiod (16 h of light), temperature of $23{ }^{\circ} \mathrm{C}$ during the day and $17{ }^{\circ} \mathrm{C}$ at night, and $50-80 \%$ relative humidity.

Moisture and EC in the pots were measured with the WET sensor (Delta Devices, Cambridge, England) at the beginning and during the treatments, as long as it was permitted by the device's limitations. Pot substrates were collected at the end of the treatments, and moisture and EC were determined in the laboratory. Moisture was determined by the gravimetric method. The samples were dried in an oven at $105{ }^{\circ} \mathrm{C}$ until they reached constant weight and then weighed again to calculate the water content as $\mathrm{WC} \%=[(\mathrm{FW}-\mathrm{DW}) / \mathrm{FW}] \times 100$, where $\mathrm{FW}$ and $\mathrm{DW}$ are the fresh and dry weights of the substrate samples.

For EC measurements, samples were collected from each pot, air-dried and then passed through a $2 \mathrm{~mm}$ sieve. A soil: water suspension (1:5) was prepared in deionised water and mixed for one hour at 
$600 \mathrm{rpm}$ and $21{ }^{\circ} \mathrm{C}$ before being filtered. Electrical conductivity was measured with a Crison 522 conductivity-meter and expressed in $\mathrm{dS} \mathrm{m}^{-1}$.

After one month of treatment, the aerial parts and the roots of the plants were harvested and weighed separately, and several growth parameters were measured: Fresh weight of leaves (FWL) and roots (FWR), water content percentage of leaves (WCL) and roots (WCR), and leaf number (LN). Water content percentage in leaves was calculated as indicated above for the soil samples, except that the plant material was dried at $65^{\circ} \mathrm{C}$.

\section{Photosynthetic pigments}

Chlorophyll a (Chl a), chlorophyll b ( Chl b) and total carotenoids (Caro) were quantified according to the method reported by Lichtenthaler and Wellburn (1983), from $0.1 \mathrm{~g}$ of fresh leaves ground in $30 \mathrm{~mL}$ of ice-cold $80 \%$ acetone, mixed by vortexing and then centrifuged. The absorbance of the supernatant was measured at 663, 646 and $470 \mathrm{~nm}$, and the concentration of each group of compounds was calculated according to equations previously described (Lichtenthaler and Wellburn 1983). Pigment concentrations were expressed in $\mathrm{mg} \mathrm{g}^{-1} \mathrm{DW}$.

\section{Osmolytes}

Proline (Pro) content was quantified using fresh leaf material, according to the ninhydrin-acetic acid method of Bates et al. (1973). Pro was extracted in $3 \%$ aqueous sulphosalicylic acid, the extract was mixed with acid ninhydrin solution, incubated for one $h$ at $95^{\circ} \mathrm{C}$, cooled on ice and then extracted with two volumes of toluene. The absorbance of the supernatant was read at $520 \mathrm{~nm}$, using toluene as a blank. Pro concentration was expressed as $\mu \mathrm{mol} \mathrm{g}{ }^{-1} \mathrm{DW}$.

Total soluble sugars (TSS) were measured according to a previously published procedure (Dubois et al. 1956). Fresh leaf material was ground in liquid $\mathrm{N}_{2}$ and extracted with $80 \%(\mathrm{v} / \mathrm{v})$ methanol. After mixing in a rocker shaker for $24 \mathrm{~h}$., the samples were centrifuged at 12,000 rpm for $10 \mathrm{~min}$; supernatants were collected, appropriately diluted with water and supplemented with concentrated sulphuric acid and 5\% phenol. After $20 \mathrm{~min}$ incubation at room temperature, the absorbance was measured at $490 \mathrm{~nm}$. TSS concentrations were expressed as equivalents of glucose, used as the standard (mg eq. glucose $\mathrm{g}^{-1} \mathrm{DW}$ ).

Oxidative stress markers and non-enzymatic antioxidants

Leaf hydrogen peroxide contents in both, control and salt-treated plants were quantified as previously described (Loreto and Velikova 2002). Fresh leaf material $(0.05 \mathrm{~g})$ was extracted with a $0.1 \%(\mathrm{w} / \mathrm{v})$ trichloroacetic acid (TCA) solution, followed by centrifugation of the extract. The supernatant was thoroughly mixed with one volume of $10 \mathrm{mM}$ potassium phosphate buffer ( $\mathrm{pH} 7.0$ ) and two volumes of $1 \mathrm{M}$ potassium iodide. The absorbance of the sample was determined at $390 \mathrm{~nm}$. Hydrogen peroxide concentrations were calculated against an $\mathrm{H}_{2} \mathrm{O}_{2}$ standard calibration curve and expressed as $\mu \mathrm{mol} \mathrm{g} \mathrm{g}^{-1} \mathrm{DW}$.

Malondialdehyde (MDA), total phenolic compounds (TPC), and total flavonoids (TF) were quantified in the same methanol extracts of fresh leaf material used for TSS measurements. MDA was determined according to the method of Hodges et al. (1999), with some modifications (Taulavuori et al. 2001). The extracts were mixed with $0.5 \%$ thiobarbituric acid (TBA) prepared in 20\% TCA and then incubated at $95{ }^{\circ} \mathrm{C}$ for $20 \mathrm{~min}$. After subtracting the non-specific absorbance at 440 and $600 \mathrm{~nm}$, the MDA contents were calculated using the equation included in Taulavuori et al. (2001), based on the extinction coefficient at $532 \mathrm{~nm}$ of the MDA-TBA adduct $\left(155 \mathrm{mM}^{-1} \mathrm{~cm}^{-1}\right)$. Control samples (extracts mixed with $20 \%$ TCA without TBA) were processed in parallel. The concentration of MDA was finally expressed as nmol $\mathrm{g}^{-1} \mathrm{DW}$.

TPC were quantified, according to Blainski et al. (2013), by reaction with the Folin-Ciocalteu reagent. The methanol extracts were mixed with sodium bicarbonate and the reagent, incubated at room temperature in the dark for $90 \mathrm{~min}$ and the absorbance was recorded at $765 \mathrm{~nm}$. Gallic acid (GA) was used as standard, and the measured TPC concentrations were expressed as GA equivalents (mg eq. $\mathrm{GA}^{-1} \mathrm{DW}$ ).

Total 'antioxidant flavonoids' (TF) were determined by a previously described method (Zhishen et al. 1999), based on the nitration of aromatic rings containing a catechol group, by incubation with $\mathrm{NaNO}_{2}$, followed by reaction with $\mathrm{AlCl}_{3}$ at alkaline $\mathrm{pH}$. After the reaction, the absorbance of the samples 
was determined at $510 \mathrm{~nm}$, and TF contents were expressed as equivalents of the catechin standard (mg eq. $\mathrm{C} \mathrm{g}^{-1} \mathrm{DW}$ ).

\section{Antioxidant enzymatic activity}

Antioxidant enzyme activities were determined, at room temperature $\left(25{ }^{\circ} \mathrm{C}\right)$, in crude protein extracts prepared from fresh plant material as described by Gil et al. (2014). Samples were ground in the presence of liquid $\mathrm{N}_{2}$ and then mixed with extraction buffer [20 mM Hepes, pH 7.5, $50 \mathrm{mM} \mathrm{KCl,} 1 \mathrm{mM}$ EDTA, $0.1 \%$ (v/v) Triton X-100, $0.2 \%$ (w/v) polyvinylpyrrolidone, $0.2 \%(\mathrm{w} / \mathrm{v})$ polyvinylpolypyrrolidone and $5 \%$ (v/v) glycerol]. A $1 / 10$ volume of 'high salt buffer' (225 mM Hepes, $\mathrm{pH} 7.5,1.5 \mathrm{M} \mathrm{KCl}$ and $22.5 \mathrm{mM}$ $\mathrm{MgCl}_{2}$ ) was added to each sample, and the homogenates were centrifuged for $20 \mathrm{~min}$ at $20,000 \mathrm{~g}$ and $4^{\circ} \mathrm{C}$. Supernatants were collected, concentrated in U-Tube TM concentrators (Novagen, Madison, WI, USA), and centrifuged to remove precipitated material. The final samples (referred to as 'protein extracts') were divided into aliquots, flash-frozen in liquid $\mathrm{N}_{2}$ and stored at $-75^{\circ} \mathrm{C}$ until used for enzyme assays. Protein concentration in the extracts was determined by the Bradford's (1976) method, using the Bio-Rad commercial reagent and bovine serum albumin (BSA) as the standard.

Superoxide dismutase (SOD) activity in the protein extracts was determined according to Beyer and Fridovich (1987) by following spectrophotometrically (at $560 \mathrm{~nm}$ ) the inhibition of nitroblue tetrazolium (NBT) photoreduction; the reaction mixtures contained riboflavin as the source of superoxide radicals. One SOD unit was defined as the amount of enzyme causing 50\% inhibition of NBT photoreduction under the assay conditions.

Catalase (CAT) activity was determined, according to Aebi (1984), following the decrease in absorbance at $240 \mathrm{~nm}$ due to the consumption of $\mathrm{H}_{2} \mathrm{O}_{2}$ added to the protein extracts. One CAT unit was defined as the amount of enzyme that will decompose one mmol of $\mathrm{H}_{2} \mathrm{O}_{2}$ per minute at $25^{\circ} \mathrm{C}$.

Ascorbate peroxidase (APX) activity was determined as described by Nakano and Asada (1981) by measuring the decrease in absorbance at $290 \mathrm{~nm}$, which accompanies ascorbate oxidation as the reaction progresses. One APX unit was defined as the amount of enzyme required to consume one mmol of ascorbate per minute at $25^{\circ} \mathrm{C}$.

Glutathione reductase (GR) activity was determined according to Connell and Mullet (1986), following the oxidation of NADPH [the cofactor in the GR-catalysed reduction of oxidised glutathione (GSSG)] by the decrease in absorbance at $340 \mathrm{~nm}$. One GR unit was defined as the amount of enzyme that will oxidise one mmol of NADPH per minute at $25^{\circ} \mathrm{C}$.

Statistical analysis

Data were analysed using the programme Statgraphics Centurion XVII (Statgraphics Technologies, The Plains, VA, USA). All mean values throughout the text are based on five biological replicates. Significant differences between treatments were tested by one-way analysis of variance (ANOVA) at the 95\% confidence level, and post hoc comparisons were made using Tukey's HSD test at $p<0.05$. A two-way analysis of variance (ANOVA) was performed for all traits analysed to check the interaction between the species and the treatments. A principal component analysis (PCA) was used to check the similarity in the responses to water and salt stress between the two species.

\section{Results}

Climatic analysis

As it can be observed in the climatic diagram calculated for the period 2001-2019 (Fig. 1a), there is a strong water deficit in summer in the area of study, which belongs to the thermo-Mediterranean climate belt, specific for coastal and low-altitude zones, according to the Worldwide Bioclimatic Classification System (1996-2020). The evapotranspiration surpasses the rainfall amount in all the years analysed (Fig. 1b).

Evapotranspiration did not vary much during the last two decades, although a slight increase can be noticed in the last few years. On the contrary, both mean temperatures and evapotranspiration curves showed a substantial variation from one year to another. 


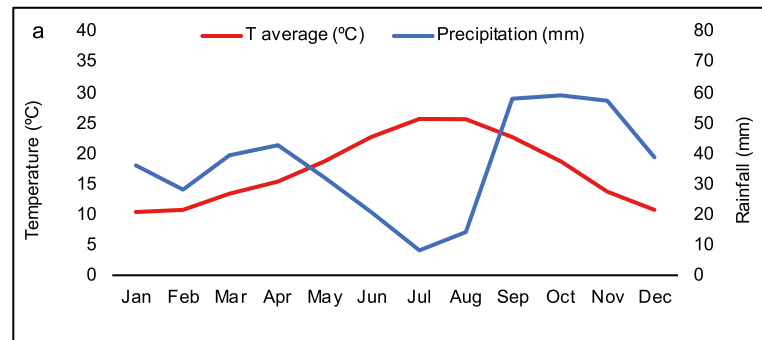

Fig. 1 Climatic characteristics in the area of study. Climatic diagram calculated for the period 2001-2019 (a); Evolution of mean temperature, rainfall and evapotranspiration in the

Trimestral variation of the main climatic parameters (mean, maximal and minimal temperatures, rainfall and evapotranspiration) is presented as supplementary material in Suppl. Table 1. A strong variation of the trimestral rainfall was detected, with minimal values in the third trimester and maximal in the fourth, coinciding with the general Mediterranean climate pattern, characterised by dry summers and rainfall mainly in autumn.

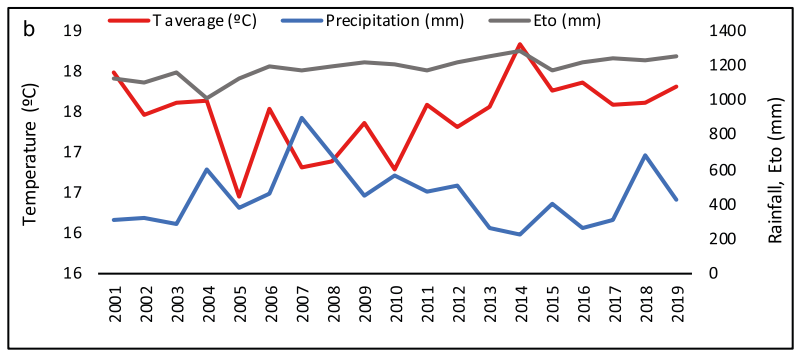

study area (b). Data from the meteorological station of Beinfaio (Valencia), located near the site of the field study, obtained from SIAR (2020)

\section{Population censuses}

Results of censuses for the two species are shown in Table 1. During the period of population monitoring (2004-2020), three of the four previously known populations of $L$. dufourii disappeared: A (in 2007-2008), C (in 2008-2009) and D (in 2007-2008).

Table 1 Censuses of the L. albuferae (LA) and L. dufourii (LD) populations, performed in the Albufera Natural Park

\begin{tabular}{|c|c|c|c|c|c|c|c|c|c|}
\hline $\mathrm{X}$ & 731,022 & 731,395 & 731,469 & 732,091 & 730,987 & 731,592 & 731,386 & 730,217 & 730,543 \\
\hline Y & $4,357,733$ & $4,358,286$ & $4,358,185$ & $4,356,743$ & $4,357,713$ & $4,357,785$ & $4,358,355$ & $4,362,094$ & $4,361,434$ \\
\hline Species & LA & LD & $\mathrm{LD}$ & LD & $\mathrm{LD}$ & LD & LD & LD & $\mathrm{LD}$ \\
\hline MU & Racó de l'Olla 1 & Devesa B & Devesa E & Devesa 2 & Racó de l'Olla & Devesa A & Devesa C & Devesa D & Devesa 1 \\
\hline 2004 & & & & & & 10 & & & \\
\hline 2005 & & 13 & & & & 10 & 28 & & \\
\hline 2006 & & 15 & & & & 7 & 31 & 21 & \\
\hline 2007 & & 9 & & & & 3 & 98 & 11 & \\
\hline 2008 & & 12 & & & & 0 & 31 & 0 & \\
\hline 2009 & & 34 & & & & 0 & 0 & 0 & \\
\hline 2010 & & 37 & & & & 0 & 0 & 0 & \\
\hline 2011 & & 44 & & & & - & 0 & 0 & \\
\hline 2012 & & 50 & & & & 0 & 0 & - & \\
\hline 2013 & & 45 & & & & 0 & 0 & - & \\
\hline 2014 & & 40 & & 328 & & 0 & 0 & 0 & 170 \\
\hline 2015 & & 241 & & 648 & & - & 0 & 0 & 175 \\
\hline 2016 & & 263 & & 1822 & & 0 & 0 & 0 & 89 \\
\hline 2017 & 238 & 133 & & 120 & 38 & 0 & 0 & 0 & 0 \\
\hline 2018 & 243 & 374 & & 809 & 38 & - & 0 & - & 11 \\
\hline 2019 & 39 & 94 & & 27 & 0 & - & 0 & - & 3 \\
\hline 2020 & 255 & 77 & 17 & 3 & 0 & 0 & 0 & 0 & 17 \\
\hline
\end{tabular}

$M U$ monitoring units, - not censed 
The extinction of populations A, C and D may be closely related to the high rainfall amount recorded in 2007 and 2008 (see Suppl. Table 1 and Fig. 1b).

A similar situation could occur for $L$. dufourii plants in the Devesa B monitoring unit, situated at a slightly higher level than the surrounding saline basins, unlike the previous ones. After several years with a low number (50 or less) of registered individuals, this monitoring unit experienced a notable increase between 2014 and 2015, from 40 to 241 specimens. This increase occurred after the succession of two very dry years, 2013 (only $263.8 \mathrm{~mm}$ ) and $2014(224.40 \mathrm{~mm})$. Population levels remained high in subsequent years, with a minimum of 133 individuals (in 2017) and a maximum of 374 (in 2018). However, after the intense rainfall recorded in 2018 $(684.02 \mathrm{~mm})$, the population showed a sharp decline again, with only 94 specimens registered in 2019.

Vegetation analysis

Vegetation inventories of plants communities were performed in 22 locations, corresponding to different salt marshes in the Albufera Natural Park. Each inventory was accompanied by the collection of soil data obtained with a portable sensor. Suppl. Table 2 summarises the habitat characteristics of each site (the extension and coverage of the plant community), soil moisture and electrical conductivity, the list of species present in the community and their coverage. Two species had a higher presence in some of the inventories, equal to 4 in the Braun-Blanquet scale: Sarcocornia fruticosa, a structural shrubby species of the Mediterranean salt marshes, but also Spartina patens, an invasive with an increasing presence in recent years in the area of study. The soil electrical conductivity measured by the WET sensor near the plants of the two studied species in all inventories was higher in the case of $L$. dufourii, but it is necessary to take into consideration that $L$. albuferae was found in one unique location; thus, this finding does not demonstrate a better salt tolerance of $L$. dufourii.

\section{Soil characteristics}

Soil samples, collected in the summer of 2019 from the unique location of $L$. albuferae and three salt marshes with $L$. dufourii, all located in the Albufera Natural Park, were analysed. From each location, three soil samples were taken in the vicinity of the plants at two depths, $0-10 \mathrm{~cm}$ and $10-20 \mathrm{~cm}$. Their physical and chemical properties are summarised in Table 2.

All soils had a sandy texture. The percentage of sand represented the primary component, with low amounts of silt and clays. The soil $\mathrm{pH}$ is neutral, and the salinity in the superficial layer $(0-10 \mathrm{~cm})$ was higher than at $10-20 \mathrm{~cm}$ depth - which is the area
Table 2 Soil characteristics in the salt marshes with Limonium albuferae and L. dufourii in the Albufera Natural Park

Values represent means followed by $\mathrm{SD}(n=3)$. CEC, cationic exchange capacity, EC, Electric conductivity in saturated paste. Same letters indicate homogenous groups according to the Tukey test $(p \leq 0.05)$

\begin{tabular}{|c|c|c|c|c|}
\hline \multirow[t]{2}{*}{ Parameter } & \multicolumn{2}{|l|}{$0-10 \mathrm{~cm}$ depth } & \multicolumn{2}{|l|}{$10-20 \mathrm{~cm}$ depth } \\
\hline & L. albuferae & L. dufourii & L. albuferae & L. dufourii \\
\hline Sand (\%) & $99.50 \pm 0.07^{\mathrm{b}}$ & $92.69 \pm 1.79^{\mathrm{a}}$ & $94.90 \pm 0.61^{\mathrm{b}}$ & $91.11 \pm 0.63^{\mathrm{a}}$ \\
\hline Silt (\%) & $0.35 \pm 0.05^{\mathrm{a}}$ & $5.11 \pm 1.25^{\mathrm{b}}$ & $3.57 \pm 0.43^{\mathrm{ab}}$ & $6.23 \pm 0.22^{\mathrm{b}}$ \\
\hline Clay (\%) & $0.15 \pm 0.02^{\mathrm{a}}$ & $2.19 \pm 0.53^{\mathrm{b}}$ & $1.53 \pm 0.18^{\mathrm{a}}$ & $2.67 \pm 0.19^{b}$ \\
\hline Bulk density $\left(\mathrm{g} \mathrm{cm}^{-3}\right)$ & $1.10 \pm 0.07^{\mathrm{a}}$ & $1.30 \pm 0.05^{\mathrm{a}}$ & $1.17 \pm 0.09^{\mathrm{a}}$ & $1.31 \pm 0.06^{\mathrm{a}}$ \\
\hline Porosity $(\%)$ & $58.46 \pm 2.73^{\mathrm{b}}$ & $51.00 \pm 2.14^{\mathrm{aA}}$ & $55.80 \pm 3.45^{\mathrm{a}}$ & $50.57 \pm 3.73^{\mathrm{a}}$ \\
\hline Carbonates (\%) & $23.21 \pm 0.64^{\mathrm{a}}$ & $22.07 \pm 1.63^{\mathrm{a}}$ & $24.56 \pm 1.56^{\mathrm{a}}$ & $26.05 \pm 4.09^{\mathrm{a}}$ \\
\hline Organic Matter (\%) & $1.66 \pm 0.38^{\mathrm{a}}$ & $0.97 \pm 0.37^{\mathrm{a}}$ & $0.71 \pm 0.08^{\mathrm{a}}$ & $0.61 \pm 0.25^{\mathrm{a}}$ \\
\hline $\mathrm{pH}$ & $7.86 \pm 0.21^{\mathrm{a}}$ & $7.42 \pm 0.18^{\mathrm{a}}$ & $7.87 \pm 0.03^{\mathrm{a}}$ & $7.79 \pm 0.14^{\mathrm{a}}$ \\
\hline $\mathrm{EC}\left(\mathrm{dS} \mathrm{m} \mathrm{m}^{-1}\right)$ & $12.75 \pm 4.93^{\mathrm{a}}$ & $37.91 \pm 6.24^{\mathrm{b}}$ & $10.33 \pm 2.38^{\mathrm{a}}$ & $15.73 \pm 1.98^{\mathrm{a}}$ \\
\hline $\mathrm{Na}^{+}\left(\right.$meq $\left.\mathrm{L}^{-1}\right)$ & $97.87 \pm 28.63^{\mathrm{a}}$ & $295.52 \pm 51.05^{b}$ & $74.02 \pm 22.53^{\mathrm{a}}$ & $107.63 \pm 12.95^{\mathrm{a}}$ \\
\hline $\mathrm{K}^{+}\left(\mathrm{meq} \mathrm{L} \mathrm{L}^{-1}\right)$ & $2.68 \pm 0.61^{\mathrm{a}}$ & $7.26 \pm 2.13^{\mathrm{b}}$ & $2.32 \pm 0.36^{\mathrm{a}}$ & $2.78 \pm 0.15^{\mathrm{a}}$ \\
\hline $\mathrm{Cl}^{-}\left(\right.$meq L $\left.\mathrm{L}^{-1}\right)$ & $54.85 \pm 13.02^{\mathrm{a}}$ & $252.64 \pm 49.15^{\mathrm{b}}$ & $44.51 \pm 9.28^{\mathrm{a}}$ & $76.49 \pm 15.89^{\mathrm{a}}$ \\
\hline $\mathrm{Ca}^{2+}\left(\right.$ meq L $\left.{ }^{-1}\right)$ & $11.04 \pm 1.78^{\mathrm{a}}$ & $18.62 \pm 1.86^{\mathrm{b}}$ & $11.24 \pm 0.72^{\mathrm{a}}$ & $12.10 \pm 0.76^{\mathrm{a}}$ \\
\hline $\mathrm{Mg}^{2+}\left(\mathrm{meq} \mathrm{L}^{-1}\right)$ & $8.80 \pm 2.75^{\mathrm{a}}$ & $15.62 \pm 5.37^{\mathrm{a}}$ & $7.24 \pm 1.14^{\mathrm{a}}$ & $12.97 \pm 5.78^{\mathrm{a}}$ \\
\hline
\end{tabular}


explored by the roots of the plants -, especially in the areas with $L$. dufourii. When comparing the two species, higher EC values were obtained at the two depths for $L$. dufourii, confirming the measurement performed by the WET sensor in the natural habitats. The most abundant ion in the soil was $\mathrm{Na}^{+}$, found at a higher concentration than that of $\mathrm{Cl}^{-}$. The soil samples are also characterised by a high percentage of carbonates and divalent cations, $\mathrm{Ca}^{2+}$ and $\mathrm{Mg}^{2+}$.

Plant growth under greenhouse conditions

Substrate EC was measured with the WET Sensor at the beginning and after one week of treatment, but further measurements were not possible due to the high EC reached in the salt treatments of $400-800 \mathrm{mM} \mathrm{NaCl}$, which were beyond the capacity of the device. Therefore, the final EC was measured in an extract 1:5. EC in the pots gradually increased in parallel to the concentration applied, reaching values over tenfold higher than in the control in those watered with $800 \mathrm{mM} \mathrm{NaCl}$, for the two species (Fig. 2a). Substrate moisture decreased drastically in the WS treatment already after one week and even more after 17 days in the two species; no further measurements were possible with the WET sensor. Thus, the final moisture determination was carried out using the gravimetric method. The results indicated a similar reduction in soil moisture in the two species at the end of the WS treatments (down to around 3\%), whereas only a slight decrease was found in the presence of 400,600 and $800 \mathrm{mM} \mathrm{NaCl}$, with respect to the control and $200 \mathrm{mM} \mathrm{NaCl}$ treatments (Fig. 2b).

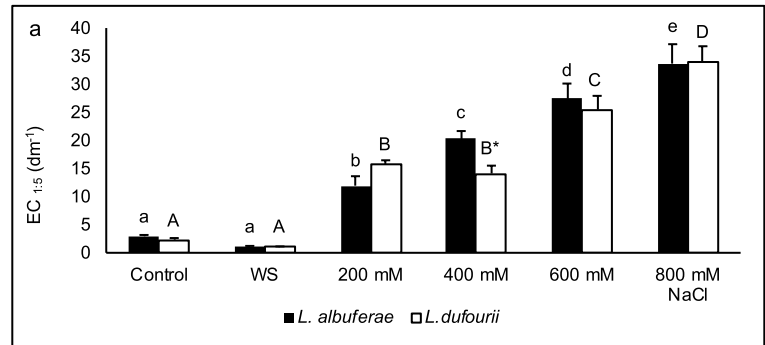

Fig. 2 Substrate electrical conductivity in a soil: water suspension (1:5) (a), and moisture (b), measured in pots with $L$. albuferae or L. dufourii at the end of $30 \mathrm{~d}$ of water stress (WS; complete withholding of irrigation) or salt stress (at the indicated $\mathrm{NaCl}$ concentrations) treatments. Same letters within
Table 3 Two-way analysis of variance (ANOVA) of treatment, species and their interactions, for the measured growth parameters

\begin{tabular}{lllll}
\hline Parameter & Treatment & Species & Interaction & Residual \\
\hline RFW & $57.48 * * *$ & 0.43 & 1.35 & 40.73 \\
RWC & $87.19 * * *$ & 0.12 & 1.51 & 11.17 \\
Lno & $56.79 * * *$ & 1.14 & $13.21 * *$ & 28.81 \\
LA & $34.10 * * *$ & 1.31 & $46.12 * * *$ & 18.54 \\
LFW & $72.24 * * *$ & $2.84 * *$ & $11.68 * * *$ & 13.22 \\
LWC & $88.98 * * *$ & $1.91 * * *$ & $5.21 * * *$ & 3.88 \\
Chl a & $37.45 * * *$ & $6.04 * *$ & 5.54 & 50.96 \\
Chl b & $48.85 * * *$ & 2.52 & 5.50 & 43.11 \\
Caro & $45.13 * *$ & 2.53 & 9.34 & 42.98 \\
\hline
\end{tabular}

Numbers represent percentages of the sum of squares (SS) at the $5 \%$ confidence level

$R F W$ root fresh weight, $R W C$ root water content, $L A$ leaf surface area, $L n o$ increment in the number of leaves, $L F W$ leaf fresh weight, $L W C$ leaf water content percentage, Chl a chlorophyll a, Chl $b$ chlorophyll b, Caro carotenoids

Analysis of the growth parameters

Stress treatments had a strong effect on all analysed growth parameters and also on the photosynthetic pigments contents, whereas the effect of species was significant only for the leaf fresh weight (LFW) and leaf water content (LWC), as well as for Chl a content. The interaction of the two factors was also significant only for leaf traits: number of leaves (Lno), leaf area (LA), mean fresh weight (LFW) and mean water content (LWC) (Table 3). Chlorophyll a showed a predominantly uncontrolled variation, as shown by the higher SS percentage of the residual.

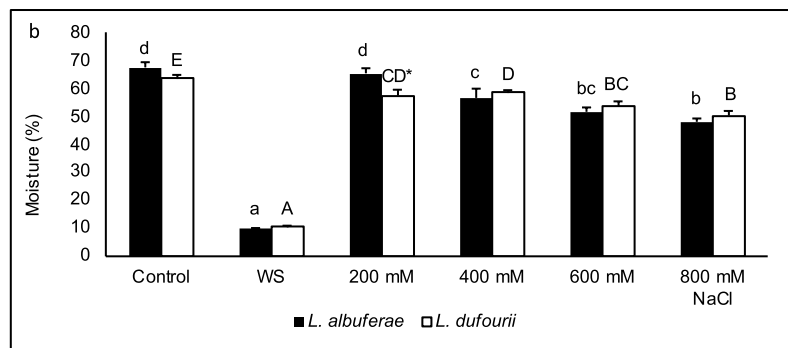

each species (lower case for L. albuferae and upper case for $L$. dufourii) indicate homogeneous groups between treatments, according to the Tukey test $(p \leq 0.05)$. Asterisks indicate significant differences between plants of the two species subjected to the same treatment $(p \leq 0.05)$ 
Figure 3 shows the variation of leaf traits according to the various applied treatments. Leaf area decreased mainly in $L$. dufourii, whereas L. albuferae showed only a smaller reduction under water stress (Fig. 3a). The leaf number strongly decreased under the highest salt concentration, but the formation of new leaves was also reduced under water stress and salt treatments in the two species (Fig. 3b). Leaf fresh weight suffered a reduction under water stress in both species and under all salt concentrations in $L$. dufourii, but only under the higher salt concentrations in L. albuferae (Fig. 3c). Leaf water content showed a similar variation in the two species being affected only by the water stress (Fig. 3d).

Osmolytes, oxidative stress markers and antioxidant systems

Several biochemical parameters, such as osmolytes (proline and total soluble sugars), oxidative stress markers (MDA and $\mathrm{H}_{2} \mathrm{O}_{2}$ ), non-enzymatic antioxidants (total phenolic compounds and flavonoids) and the activity of antioxidant enzymes (superoxide dismutase, catalase, glutathione reductase), were
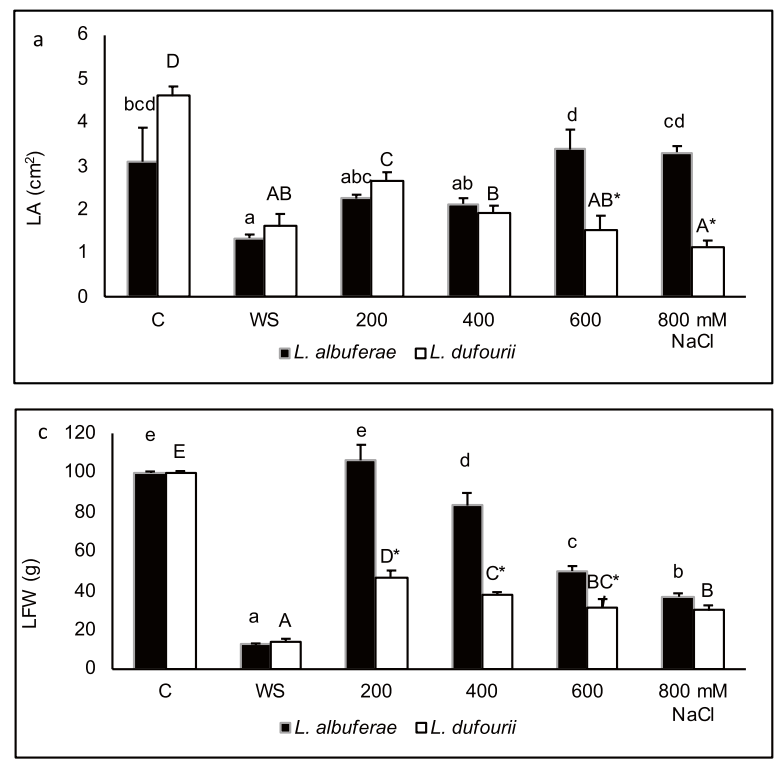

Fig. 3 Growth parameters in the two Limonium species after 30 days of water stress (WS; complete withholding of irrigation) or salt stress (at the indicated $\mathrm{NaCl}$ concentrations) treatments. Leaf area (a), variation in the number of leaves (b), leaf fresh weight (c) and leaf water content (d). Mean \pm SE values are shown $(n=5)$. Same letters within each species (lower determined in leaves of plants sampled at the end of the water stress and salt treatments.

The two-way ANOVA showed that, except MDA, all other analysed biochemical traits were significantly influenced by the treatments and, with the exception of MDA and total phenolic compounds (TPC), also by the species. The interaction between the two factors was highly significant for total soluble sugars contents (TSS) and the antioxidant enzymes activities, but not significant for Pro and TPC (Table 4). The most significant contribution to variation of MDA, TPC and TF is accounted for by the residual source of variation.

As indicated above, the variation of proline (Pro) leaf contents followed a similar pattern in the two species, increasing in parallel to the external concentration of $\mathrm{NaCl}$, and especially under water stress. The relative increase over control values in plants subjected to water deficit was 29 -fold for $L$. albuferae and 2.7-fold for L. dufourii; the corresponding values in the presence of the highest salt concentration applied, $800 \mathrm{mM} \mathrm{NaCl}$, were 17 -fold and 1.7-fold, respectively. However, it should be noted that Pro concentrations differed in the two species, being
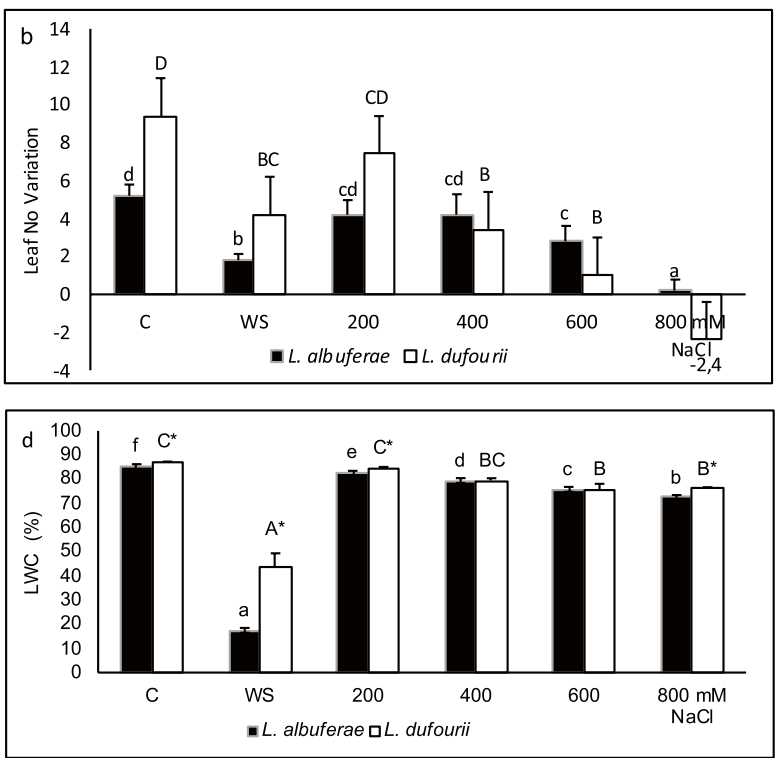

case for $L$. albuferae and upper case for $L$. dufourii) indicate homogeneous groups between treatments, according to the Tukey test $(p \leq 0.05)$. Asterisks indicate significant differences between plants of the two species subjected to the same treatment $(p \leq 0.05)$ 
Table 4 Two-way analysis of variance (ANOVA) of treatment, species and their interactions for the biochemical parameters considered

\begin{tabular}{lcccl}
\hline Parameter & Treatment & Species & Interaction & Residual \\
\hline Pro & $61.32 * * *$ & $21.35 * * *$ & 1.07 & 16.25 \\
TSS & $36.55 * * *$ & $6.97 * *$ & $20.53 * * *$ & 36.03 \\
$\mathrm{MDA}$ & 6.09 & 5.72 & $18.28 *$ & 69.91 \\
$\mathrm{H}_{2} \mathrm{O}_{2}$ & $57.95 * * *$ & $4.71 * *$ & $9.22 *$ & 28.10 \\
$\mathrm{TPC}$ & $33.80^{* * *}$ & 0.004 & 8.48 & 57.71 \\
$\mathrm{TF}$ & $17.85^{*}$ & $10.86 * *$ & $17.06 *$ & 54.21 \\
$\mathrm{SOD}$ & $39.90^{* * *}$ & $7.60 * * *$ & $24.90^{* * *}$ & 27.51 \\
$\mathrm{CAT}$ & $14.85^{* * *}$ & $50.01 * * *$ & $13.19 * * *$ & 21.95 \\
$\mathrm{GR}$ & $64.90^{* * *}$ & $4.27 * *$ & $8.59 * *$ & 22.30 \\
\hline
\end{tabular}

Numbers represent percentages of the sum of squares at the $5 \%$ confidence level

Pro proline, TSS total soluble sugars, MDA malondialdehyde, $\mathrm{H}_{2} \mathrm{O}_{2}$ hydrogen peroxide, $\mathrm{SOD}$ superoxide dismutase, $\mathrm{CAT}$ catalase, $G R$ glutathione reductase

significantly higher in L. dufourii than in L. albuferae in the control plants and under all tested stress conditions (Fig. 4a).

Under water stress, total soluble sugars (TSS) significantly increased in $L$. dufourii and decreased in L. albuferae, although the levels in non-stressed, control plants were more than four-fold higher in the latter species. Watering the plants with $800 \mathrm{mM}$ $\mathrm{NaCl}$ induced a significant increase of TSS contents in both species. When comparing the two species, apart from the controls, significant differences in TSS levels were found under water deficit and moderate (200 mM) salinity conditions, but not in the presence of $400 \mathrm{mM}$ or higher $\mathrm{NaCl}$ concentrations (Fig. 4b).
Malondialdehyde (MDA) contents did not vary in L. albuferae under any of the applied stress treatments and showed a significant (albeit small) increment only in water-stressed $L$. dufourii plants (Fig. 5a). In contrast, hydrogen peroxide decreased with respect to the corresponding controls in both species (Fig. 5b). Total phenolic compounds (TPC) showed a similar pattern of variation in response to stress in the two species, with small, in most cases non-significant changes as compared to the controls (Fig. 5c), whereas total flavonoids (TF) contents increased significantly only in plants of L. albuferae treated with $400 \mathrm{mM}$ or higher $\mathrm{NaCl}$ concentrations (Fig. 5d).

\section{Activity of antioxidant enzymes}

The specific activities of the three tested antioxidant enzymes (SOD, CAT, and GR) showed different qualitative and quantitative patterns of variation in the two species in response to the applied stress treatment (Fig. 6). In L. albuferae, compared to the basal levels in non-stressed plants, the activity of the three tested enzymes increased significantly at very high salinities $(600-800 \mathrm{mM} \mathrm{NaCl})$ but not at lower $\mathrm{NaCl}$ concentrations or under water deficit conditions (Fig. 6a, b, c). In L. dufourii, SOD increased significantly only in the presence of $800 \mathrm{mM} \mathrm{NaCl}$ and in water-stressed plants (Fig. 6a), and GR also at the highest salt concentration tested, but not under water deficit stress (Fig. 6c). In contrast, CAT activity did not show significant changes in any of the treatments (Fig. 6b). Comparing the two species, significant differences were found; higher activation of SOD and CAT under salt tress in L. albuferae, whereas, on the contrary,

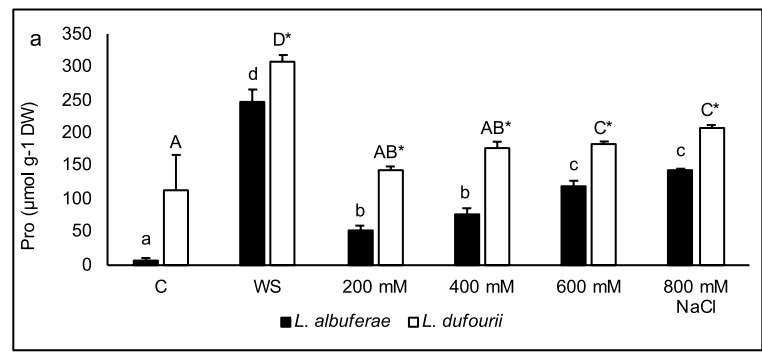

Fig. 4 Proline (a) and total soluble sugars (b) concentrations in leaves of the two Limonium species after 30 days of water stress (WS; complete withholding of irrigation) or salt stress (at the indicated $\mathrm{NaCl}$ concentrations) treatments. Mean $\pm \mathrm{SE}$ values are shown $(n=5)$. Same letters within each species

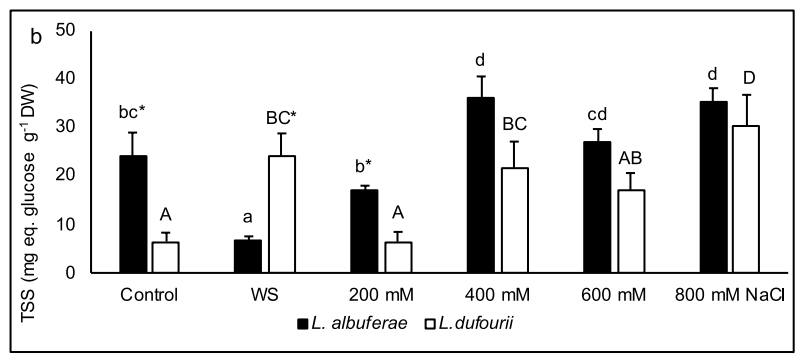

(lower case for $L$. albuferae and upper case for $L$. dufourii) indicate homogeneous groups between treatments, according to the Tukey test $(p \leq 0.05)$. Asterisks indicate significant differences between plants of the two species subjected to the same treatment $(p \leq 0.05)$ 

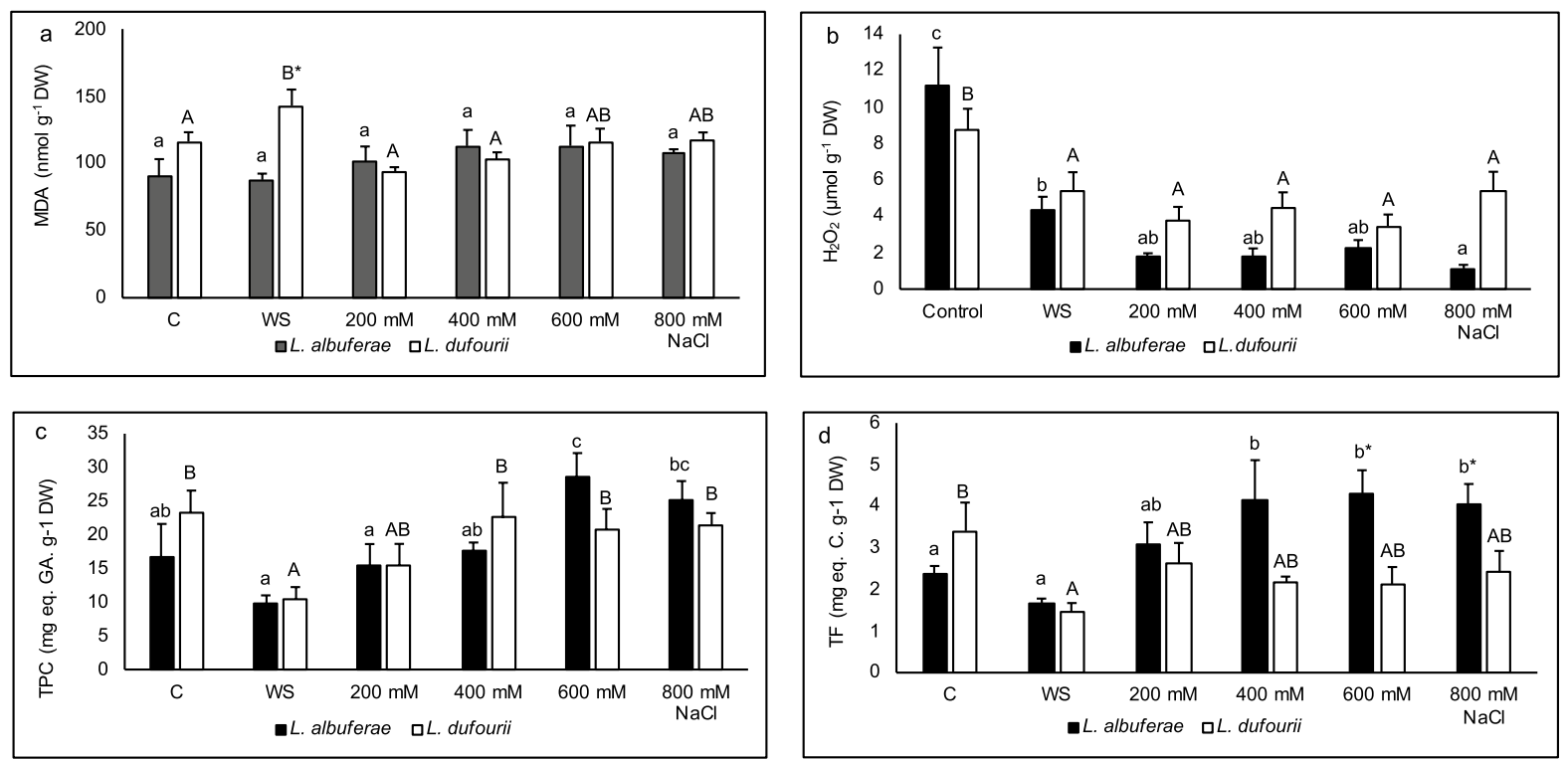

Fig. 5 Malondialdehyde (a), hydrogen peroxide (b), total phenolic compounds (c), and total flavonoids (d) concentrations in leaves of the two Limonium species after 30 days of water stress (WS; complete withholding of irrigation) or salt stress (at the indicated $\mathrm{NaCl}$ concentrations) treatments. Mean $\pm \mathrm{SE}$ values are shown $(n=5)$. Same letters within each species

higher activation of SOD and GR under water stress in L. dufourii.

\section{Principal component analysis}

A principal component analysis (PCA) was also performed, including all growth parameters, osmolytes, oxidative stress markers, antioxidants and enzyme activities determined in control and stressed plants. Five components had an Eigenvalue above 1. The biplot of the two main principal components, which together explained $67.96 \%$ of total variability, is shown in Fig. 7. The first component (X-axis), explaining $39.57 \%$ of variability, is related to the moisture of the substrate and, therefore, mainly to the water stress effect. The second component (Y-axis), explaining an additional $28.12 \%$ of variability, is related to the EC of the substrate and, as such, mostly to the salt treatments. Changes in substrate moisture correlated positively with changes in all growth parameters - especially the water content of root and leaves and leaf fresh weight - and photosynthetic pigments concentrations, which agrees with the inhibition of growth and the decrease in pigments

(lower case for $L$. albuferae and upper case for $L$. dufourii) indicate homogeneous groups between treatments, according to the Tukey test $(p \leq 0.05)$. Asterisks indicate significant differences between plants of the two species subjected to the same treatment $(p \leq 0.05)$

contents observed under water stress (Fig. 7a). On the other hand, a strong negative correlation was detected between substrate water content and Pro, reflecting the large increase in Pro levels induced by water deficit (Fig. 7a). Regarding changes in the substrate EC, strong positive correlations were found with the antioxidant systems, especially with the activity of the SOD, CAT and GR enzymes, which increased with the salt treatments, at least at high salinity (Fig. 7a). The PCA also showed a clear separation of control, water stress and salt treatments but not of the two species, which responded in a similar manner to each applied stress treatment (Fig. 7b).

\section{Discussion}

As stated in the introduction, the two studied Limonium species are extremely interesting from the conservationist perspective. Both are endemic, with a small distribution area in Eastern Spain and highly threatened due to the scarcity of their populations (a single one was known for L. albuferae) and the large fluctuations in the number of their individuals. The 
Fig. 6 Activity of the antioxidant enzymes, superoxide dismutase (SOD) (a), catalase (CAT) (b) and glutathione reductase (GR) (c), in the leaves of the two studied Limonium species after 30 days of water stress (WS; complete withholding of irrigation) or salt stress (at the indicated $\mathrm{NaCl}$ concentrations) treatments. Mean \pm SE values are shown $(n=5)$. Same letters within each species (lower case for L. albuferae and upper case for $L$. dufourii) indicate homogeneous groups between treatments, according to the Tukey test $(p \leq 0.05)$. Asterisks indicate significant differences between plants of the two species subjected to the same treatment $(p \leq 0.05)$
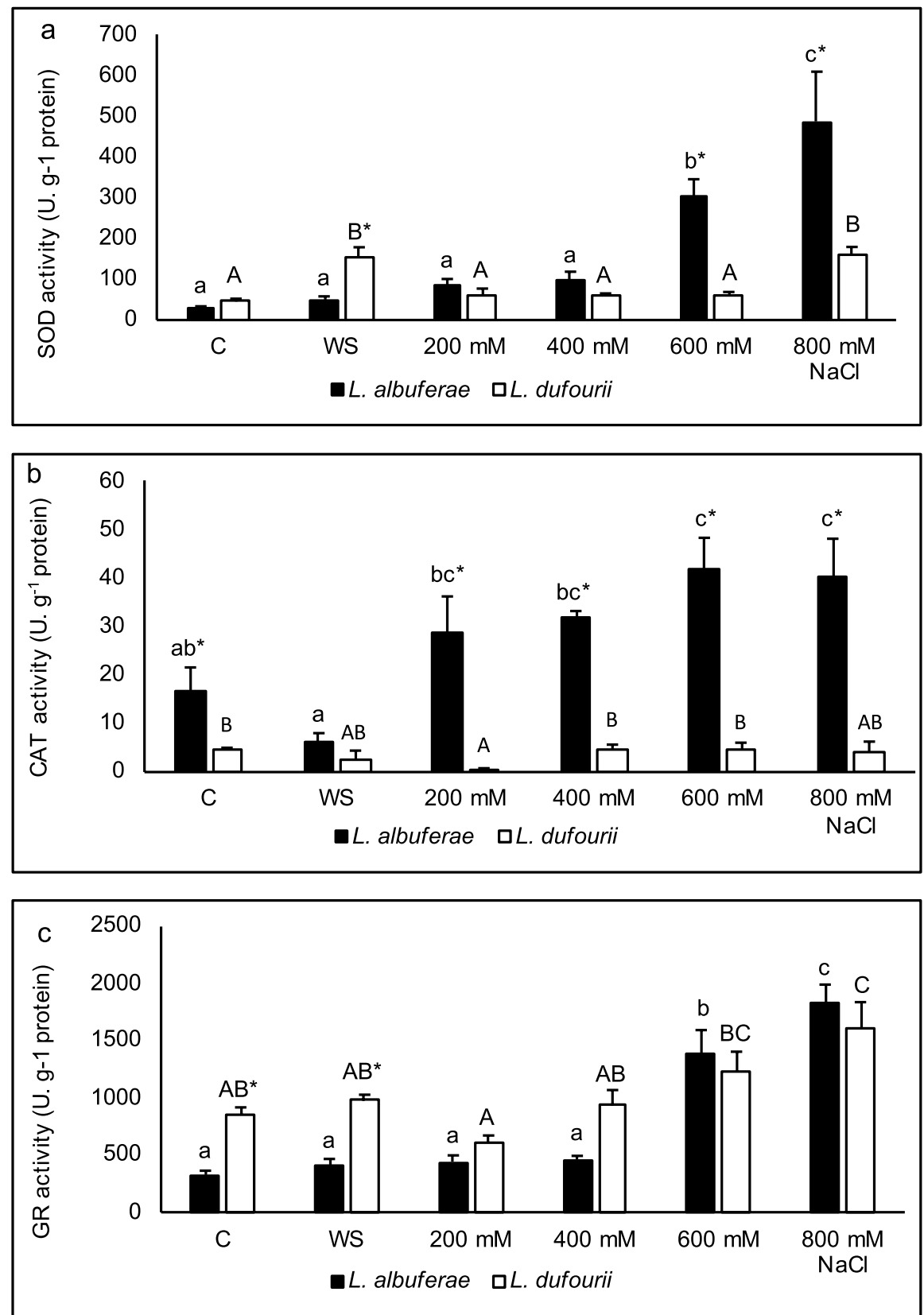

highest number of individuals of $L$. dufourii were registered in drier years, when flooding of the salt marshes did not occur or was very brief; conversely, the population declined after a year with intense rainfall. It should be taken into account that in this area of Eastern Spain, the highest concentration of precipitation occurs in autumn and, therefore, its effects on the censuses of Limonium species are detected when they are carried out in the summer of the following year. The possible effects of climatic conditions on the number of individuals of $L$. albuferae could not be assessed, as the species has been described only recently (Ferrer-Gallego et al. 2016). In 2019, an apparent decrease in the population of L. albuferae was observed; only 39 specimens were initially counted, which could be related to the intense colonisation of this site by the invasive species Spartina patens (Aiton) Muhl. However, after manual 

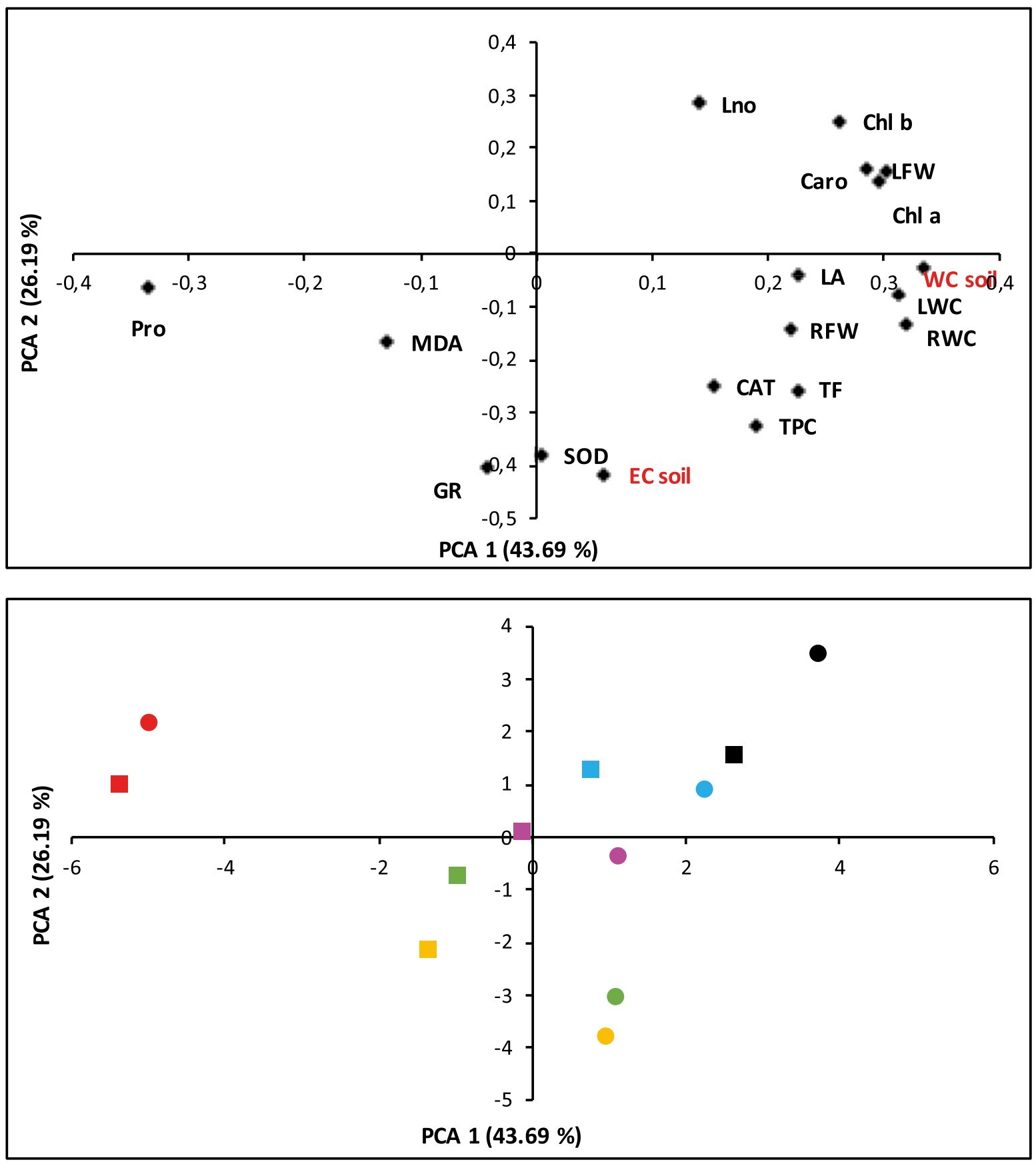

Fig. 7 Principal Component Analysis (PCA). Loading plot of the principal component analysis performed with the analysed traits (a): growth parameters, osmolytes, oxidative stress markers and non-enzymatic antioxidants levels, and antioxidant enzyme activities, in correlation to substrate moisture and EC. Scatter plot of the PCA scores (b): L. albuferae (circles) and L. dufourii (squares) plants, grown under water stress (red), and 200 (blue), 400 (purple), 600 (yellow), and 800 (green) $\mathrm{mM} \mathrm{NaCl}$, versus the corresponding non-stressed controls (black). Each symbol corresponds to the mean of the analysed plants per species and treatment $(n=5)$. Abbreviations: RFW, root fresh weight; RWC, root water content; LA, leaf surface area; Lno, increment in the number of leaves; LFW, leaf fresh weight; LWC, leaf water content; Chl a, chlorophyll a; Chl b, chlorophyll b; Caro, carotenoids; Pro, proline; TSS, total soluble sugars; MDA, malondialdehyde, $\mathrm{H}_{2} \mathrm{O}_{2}$, hydrogen peroxide; SOD, superoxide dismutase; CAT, catalase; GR, glutathione reductase 
elimination of the invasive plants, 255 individuals of L. albuferae were censed in 2020.

The soil salinities in the salt marshes where the two species were found were moderate, and in the case of L. albuferae, significantly lower than those registered for the less salt-tolerant $L$. dufourii. Moreover, the salinity of the natural habitat of $L$. albuferae was well below the limit of tolerance of the species established in the greenhouse experiments. However, due to the extreme scarcity of this species, represented by a single population, the soil analyses were performed from only one area and are not conclusive for its ecological characterisation. The peculiar rarity of $L$. albuferae is definitely not related to edaphic conditions but most likely to evolutionary factors.

Regarding the analysed soil parameters, $\mathrm{Na}^{+}$and $\mathrm{Cl}^{-}$contents in samples from $0-10 \mathrm{~cm}$ depth were 3 and 4.5-fold higher, respectively, in the areas of $L$. dufourii than in that of L. albuferae at the same depth. These differences explain the higher mean EC also detected with the WET sensor in the areas where $L$. dufourii was present. The same pattern was found for $\mathrm{K}^{+}, \mathrm{Ca}^{2+}$ and $\mathrm{Mg}^{2+}$ soil concentrations, although the differences between the areas of the two species were not as marked as for $\mathrm{Na}^{+}$and $\mathrm{Cl}^{-}$. Other soil properties relevant to plants' life, such as texture or $\mathrm{pH}$, were similar in all soil samples.

The phytosociological analysis inventories could not be ascribed to associations as the specimens of the two species are often located in areas that have been extensively altered and have suffered a geomorphological restoration. The vegetation dynamics is very rapid, subjected to flooding and, therefore, to changes in salinity. This triggers the advance and retreat in a short time of different species, and the rainfall regime has been very variable in recent years, also greatly altering the plant communities. Nevertheless, the performance of phytosociological inventories brought relevant information by revealing the abundant presence in some inventories of the invasive species Spartina patens, which was recently reported as a major threat for native halophytes in this area (Martínez-Fort and Donat-Torres 2020). Spartina patens appears to pose a severe risk also to the two endemic Limonium species, as the salt marshes where L. dufourii disappeared (Devesa A, C, and D) are completely invaded by this species. In the remaining sites, the large yearly variation in the number of individuals is related to genetic factors of $L$. dufourii, which shows very different flowering patterns, occasionally behaving as annual or monocarpic perennial (plants die after the first reproductive stage) or flowering every year. Also, it should be noticed the high frequency of Dittrichia viscosa (L.) Greuter, regarded as a native invasive species, extremely competitive at low and moderate salinities in salt marshes of the region (Al Hassan et al. 2016).

Salt marsh ecosystems are highly dynamic, characterised by large variations in the salinity of the soil at the temporal and spatial scales, as reported in previous studies performed on the territory of the Albufera Natural Park (Boscaiu et al. 2013; Gil et al. 2014; González-Orenga et al. 2020). Therefore, reintroduction or reinforcement programmes for endemic and rare salt marsh species should also consider information on their limits of tolerance to stressful environmental factors. In Mediterranean salt marshes, a general increase in average temperatures and shortterm 'heatwaves', due to climate change, will lead to increased evapotranspiration. Consequently, drought and soil salinity will also intensify, inflicting greater stress on plants and potentially causing the dieback of those less tolerant (Touchette et al. 2019).

The analysis of growth inhibition in response to the applied stress treatments indicated that the two species were mostly affected by water stress. In both, the strongest reduction in the most relevant growth parameters, leaf fresh weight and water content, was found in plants subjected to one month of water deficit, especially those of $L$. albuferae. This indicated that $L$. albuferae is much more susceptible to drought than other Limonium species growing in the study area, which were the subject of previous work (González-Orenga et al. 2019b). On the contrary, the salt-induced changes in growth parameters suggested that $L$. dufourii is more sensitive to high soil salinity than L. albuferae. Growth reduction under salt stress is a general trait in glycophytes but also in many halophytes (Flowers et al. 1986; Flowers and Colmer 2008). Only in some dicotyledonous halophytes, especially in those more salt-tolerant, low and moderate concentrations of $\mathrm{NaCl}$ stimulate growth, as we have observed in L. albuferae, in which foliar fresh weight was slightly higher in the presence of $200 \mathrm{mM}$ $\mathrm{NaCl}$ than in control plants. Stimulation of growth under low and moderate salinity conditions has been reported only in a few species of the genus Limonium, such as L. bicolor (Bunge) Kuntze (Li 2008; Wang 
et al. 2017), L. delicatulum (Girard) Kuntze (Souid et al. 2016), L. pectinatum (Aiton) Kuntze (Morales et al. 2001), or L. girardianum and L. virgatum (Al Hassan et al. 2017). In some others, such as L. stocksii, no differences with respect to the control were found up to $300 \mathrm{mM} \mathrm{NaCl}$ (Hameed et al. 2015), whereas in many species, growth was optimal in control conditions (Ben Hamed et al. 2014; Grieve et al. 2005). Contrary to the intense dehydration caused by water stress, for both species, leaf water content decreased only slightly in the plants subjected to salt stress, demonstrating the small contribution of water loss to the reduction of fresh weight.

The biochemical analyses revealed an increase of Pro contents in the two Limonium species, more pronounced in response to the water stress treatment than under salt stress. The relative increase was more accentuated in L. albuferae due to the very low Pro levels in the absence of stress, but higher absolute values were found in $L$. dufourii in all applied treatments. The accumulation of Pro to high levels under water deficit conditions agrees with its strong negative correlation with substrate water content, revealed by the PCA. Pro is also a reliable marker of salt stress, increasing in the plants in parallel with the increase in the external concentration of $\mathrm{NaCl}$; however, Pro does not seem to be directly involved in the mechanisms of salt tolerance, as it accumulates to higher absolute levels in L. dufourii, the less salt-tolerant of the two species. Pro biosynthesis in salt-stressed plants of Limonium is a well-known phenomenon and was already reported in the early work of Cavalieri and Huang (1979). In general, plant species of a particular genus tend to use only one, or very few different compounds, as functional osmolytes; one representative example is Plantago: all investigated species of this genus accumulate predominantly sorbitol in response to various abiotic stresses (Flowers and Colmer, 2008). In Limonium, however, a large variety of chemical compounds with the function of compatible solutes have been reported in different species including, besides Pro, quaternary ammonium compounds like $\beta$-alanine betaine, choline- 0 -sulfate or glycine betaine, and different soluble sugars (fructose, sucrose and glucose) and polyalcohols (e.g., inositol isomers and derivatives) (Al Hassan et al. 2017; Furtana et al. 2013; Gagneul et al. 2007; González-Orenga et al. 2019b; Hanson et al. 1991;
Morales et al. 2001; Rhodes and Hanson 1993; Tabot and Adams 2014; Tipirdamaz et al. 2006). Recently, in a metabolic profiling of these two species, we reported a gradual increase in Pro concentrations in parallel to increasing salinity but also a higher accumulation of fructose and glucose in L. albuferae (González-Orenga et al. 2019a). These data are consistent with the results presented here, indicating higher values of total soluble sugars in salt-stressed plants of this latter species.

As already mentioned, abiotic stress is associated with increased ROS production that generates oxidative stress (Das and Roychoudhury 2014; Dumanović et al. 2021). In our experiments, no significant changes in MDA levels were observed in the stressed plants, except for a slight (but significant) increase in plants of $L$. albuferae subjected to water stress; $\mathrm{H}_{2} \mathrm{O}_{2}$ levels even decreased in comparison to the non-stressed controls. Similarly, no variation in MDA and $\mathrm{H}_{2} \mathrm{O}_{2}$ under salt treatments was found in L. latifolium (Ben Hamed et al. 2014), but an increase was reported in some other species (Hameed et al. 2015; Souid et al. 2016). Several studies have shown that halophytes generally do not generate ROS in excess as they are perfectly adapted to the stressful environments where they live and possess efficient mechanisms to avoid or substantially reduce oxidative stress (Bose et al. 2014; Gil et al. 2014), and this seems to be also the case in the selected Limonium species. Phenolic compounds, especially the subgroup of flavonoids, include many secondary metabolites that are potent antioxidants and increase under stressful conditions in many plant species (Di Ferdinando et al. 2012). Many Limonium species contain efficient free radical scavengers and have strong antioxidant properties (Senizza et al. 2021; Souid et al. 2019; RuizRiaguas et al. 2020). Field studies on several Limonium species from Tunisia indicated a variation in the levels of polyphenols and flavonoids in relation to seasonal constraints in their natural habitats (Souid et al. 2018, 2019). In salt-treated plants of some species, an increase in the concentration of these compounds has been reported (Wang et al. 2016), but in others, only small increases (Souid et al. 2016) or no significant variations under water stress (GonzálezOrenga et al. 2019a, b) were observed. In the present work, the only significant increases in total phenolics or flavonoid levels were observed in salt-stressed $L$. albuferae plants. 
Phenolic compounds (including flavonoids), as other non-enzymatic antioxidants, are regarded as a secondary line of defence against oxidative stress, activated only under severe stress conditions, whereas antioxidant enzymes constitute the first ROS scavenging system (Fini et al. 2011). The specific activities of three antioxidant enzymes were determined in control and stressed plants of the two investigated species since enzymatic antioxidant mechanisms have been reported to be important for counteracting oxidative stress in Limonium under salt ( $\mathrm{Li}$ 2008; Souid et al. 2016; Zhang et al. 2014) and drought (Souid et al. 2018) stress conditions. SOD is the first enzyme to be activated in response to stress as it catalyses the dismutation of superoxide radicals into $\mathrm{O}_{2}$ and $\mathrm{H}_{2} \mathrm{O}_{2}$ (Alscher et al. 2002). CAT complements the activity of SOD by decomposing the produced $\mathrm{H}_{2} \mathrm{O}_{2}$ into $\mathrm{O}_{2}$ and $\mathrm{H}_{2} \mathrm{O}$ and is induced by the accumulation of its substrate (Gunes et al. 2007). Glutathione reductase (GR) contributes to recover and maintain the adequate cellular redox state by reducing oxidised glutathione (GSSG) to its reduced form (GSH), using NADPH as a cofactor (Hameed et al. 2015). Changes in the activities of these enzymes in response to stress followed different qualitative and quantitative patterns regarding both the stress treatment and the species. Thus, water deficit induced SOD activity in $L$. dufourii, but no significant changes with respect to the controls were observed for the other two enzymes in this species, nor in L. albuferae plants for any of the three tested enzymes. Therefore, it appears that the activation of enzymatic antioxidant mechanisms against water stress is more efficient in $L$. dufourii than in L. albuferae, which may contribute to the relatively higher drought tolerance of the former species. Conversely, in the more salt-tolerant L. albuferae, the three antioxidant enzyme activities increase significantly in response to the 600 and $800 \mathrm{mM} \mathrm{NaCl}$ treatments, whereas in L. dufourii SOD and GR (but not CAT) activities also increased, but to lower levels and only under the presence of the highest salt concentration tested.

\section{Conclusions}

The field study did not reveal a clear correlation between the number of individuals censed in the analysed populations with the climatic conditions. The vegetation analysis underlined the presence of invasive species, mostly Spartina patens, with a notable presence in some inventories. Although in the natural habitats, L. albuferae is found in sites with lower salinity, the observed changes in several growth and biochemical variables in plants of the two selected Limonium species subjected to stress treatments under controlled greenhouse conditions, indicated that $L$. albuferae is more salt-tolerant than $L$. dufourii but more susceptible to drought stress. Conversely, L. dufourii is more drought-tolerant but more saltsensitive than L. albuferae. In its natural habitat in the salt marsh, L. dufourii appears to be sensitive to prolonged flooding. Proline was synthesised in both species, especially under water stress, whereas MDA and $\mathrm{H}_{2} \mathrm{O}_{2}$ did not show a significant variation. The activity of antioxidant enzymes plays the most important role in the mitigation of oxidative stress in both species and both stress types. Increased accumulation of phenolic compounds in the two species, and flavonoids in the more salt-tolerant $L$. albuferae, also contribute to alleviating oxidative stress in the presence of high salt concentrations.

The results presented here may be useful in the conservation management of the two species. Salinity does not seem to threaten the future reintroduction of specimens in salt marshes, as the two species under controlled conditions tolerated salinities far beyond those in their natural environments. Water scarcity, however, may be a problem for L. albuferae, which proved to be more susceptible to water deficit. On the other hand, L. dufourii should not be introduced in sites prone to prolonged flooding. The field study also established that, besides abiotic stress factors, competition with invasive species could be a major threat to the preservation of these species in their natural habitats. These data should be considered in the design and implementation of conservation, reinforcement or reintroduction programmes and for the general management of the threatened populations of these rare and endemic Limonium species.

Supplementary Information The online version contains supplementary material available at https://doi.org/10.1007/ s11104-021-05059-9.

Acknowledgements This research was supported by the project AICO/2017/039 from Generalitat Valenciana. We are indebted to Dr Inmaculada Bautista (Universitat Politècnica de 
Valencia, Spain) for her valuable suggestions for improving the manuscript. Thanks to Inmaculada Ferrando Pardo for helping in the study and conservation of the seeds in the Centre for Forest Research and Experimentation of the Valencian Region (CIEF).

Open Access This article is licensed under a Creative Commons Attribution 4.0 International License, which permits use, sharing, adaptation, distribution and reproduction in any medium or format, as long as you give appropriate credit to the original author(s) and the source, provide a link to the Creative Commons licence, and indicate if changes were made. The images or other third party material in this article are included in the article's Creative Commons licence, unless indicated otherwise in a credit line to the material. If material is not included in the article's Creative Commons licence and your intended use is not permitted by statutory regulation or exceeds the permitted use, you will need to obtain permission directly from the copyright holder. To view a copy of this licence, visit http://creativecommons.org/licenses/by/4.0/.

\section{References}

Aebi H (1984) Catalase in Vitro Method Enzymol 105:121-126

Aguilella A, Fos S, Laguna E (2010) Catálogo Valenciano de especies de flora amenazadas. Generalitat Valenciana, Valencia

Al Hassan M, Chaura J, López-Gresa MP, Borsai O, Daniso E, Donat-Torres MP, Mayoral O, Vicente O, Boscaiu M (2016) Native-invasive plants vs. halophytes in Mediterranean salt marshes: stress tolerance mechanisms in two related species. Front Plant Sci 7:473. https://doi.org/10. 3389/fpls.2016.00473

Al Hassan M, Estrelles E, Soriano P, López-Gresa MP, Bellés JM, Boscaiu M, Vicente O (2017) Unraveling salt tolerance mechanisms in halophytes: a comparative study on four Mediterranean Limonium species with different geographic distribution patterns. Front Plant Sci 8:1438. https://doi.org/10.3389/fpls.2017.01438

Alscher RG, Erturk N, Heath LS (2002) Role of superoxide dismutases (SODs) in controlling oxidative stress in plants. J Exp Bot 53:1331-1341

Apel K, Hirt H (2004) Reactive oxygen species: metabolism, oxidative stress, and signal transduction. Annu Rev Plant Biol 55:373-399

Ballester JA, Díes B, Hernández Muñoz JA, Laguna E, Oltra C, Palop S, Urios G (2003) Parques naturales de la Comunidad Valenciana. Generalitat Valenciana, Valencia

Bates LS, Waldren RP, Teare ID (1973) Rapid determination of free proline for water stress studies. Plant Soil 39:205-207

Ben Hamed K, Chibani F, Abdelly C, Magne C (2014) Growth, sodium uptake and antioxidant responses of coastal plants differing in their ecological status under increasing salinity. Biologia 69:193-201. https://doi. org/10.2478/s11756-013-0304-1

Beyer W, Fridovich I (1987) Assaying for superoxide dismutase activity: some large consequences of minor changes in conditions. Anal Biochem 161:559-566
Blainski A, Lopes GC, Pallazzo De Mello JC (2013) Application and analysis of the Folin Ciocalteu method for the determination of the total phenolic content from Limonium brasiliense L. Molecules 18:6852-6865. https:// doi.org/10.3390/molecules 18066852

Boscaiu M, Lull C, Llinares J, Vicente O, Boira H (2013) Proline as a biochemical marker in relation to the ecology of two halophytic Juncus species. J Plant Ecol 6:177-186

Bose J, Rodrigo-Moreno A, Shabala S (2014) ROS homeostasis in halophytes in the context of salinity stress tolerance. J Exp Bot 65:1241-1257

Bouyoucos GJ (1962) Hydrometer method improved for making particle size analysis of soils. Agron J 54:464-465

Bradford MM (1976) A rapid and sensitive method for the quantitation of microgram quantities of protein utilizing the principle of protein-dye binding. Anal Biochem 72:248-254

Braun-Blanquet J (1964) Pflanzensoziologie. Grundzge der Vegetationskunde, 3rd edn. Springer, Wien-New York

Cavalieri AJ, Huang AHC (1979) Evaluation of proline accumulation in the adaptation of diverse species of marsh halophytes to the saline environment. Am J Bot 66:307-312

Choudhary A, Kumar A, Kaur N (2019) ROS and oxidative burst: roots in plant development. Plant Divers 42:3343. https://doi.org/10.1016/j.pld.2019.10.002

Connell JP, Mullet JE (1986) Pea chloroplast glutathione reductase: purification and characterization. Plant Physiol 82:351-356

Das K, Roychoudhury A (2014) Reactive oxygen species (ROS) and response of antioxidants as ROS-scavengers during environmental stress in plants. Front Environ Sci 2:53. https://doi.org/10.3389/fenvs.2014.00053

Del Río LA, Palma JM, Sandalio LM, Corpas FJ, Pastori GM, Bueno P, López-Huertas E (1996) Peroxisomes as a source of superoxide and hydrogen peroxide in stressed plants. Biochem Soc Trans 2:434-438

Di Ferdinando M, Brunetti C, Fini A, Tattini M (2012) Flavonoids as antioxidants in plants under abiotic stresses. In: Ahmad P, Prasad M (eds) Abiotic stress responses in plants. Springer, New York. https://doi.org/10.1007/ 978-1-4614-0634-1_9

Dubois M, Gilles KA, Hamilton JK, Reberd PA, Smith F (1956) Colorimetric method for determination of sugars and related substances. Anal Chem 28:350-356

Dumanović J, Nepovimova E, Natić M, Kuča K, Jaćević V (2021) The significance of reactive oxygen species and antioxidant defense system in plants: a concise overview. Front Plant Sci 6(11):552969. https://doi.org/10. 3389/fpls.2020.552969

Euro+Med (2006+): Euro+Med PlantBase - the information resource for Euro-Mediterranean plant diversity. Published on the Internet http://ww2.bgbm.org/EuroPlusMed/. Accessed 10 June 2020

Ferrer-Gallego PP, Roselló R, Rosato M, Rosselló JA, Laguna E (2016) Limonium albuferae (Plumbaginaceae), a new polyploid species from the Eastern Iberian Peninsula. Phytotaxa 252:114-122

Fini A, Brunetti C, Di Ferdinando M, Ferrini F, Tattini M (2011) Stress-induced flavonoid biosynthesis and the 
antioxidant machinery of plants. Plant Signal Behav 6:709-711

Flowers TJ, Colmer TD (2008) Salinity tolerance in halophytes. New Phytol 17:945-963

Flowers TJ, Hajibagheri MA, Clipson NJW (1986) Halophytes. Q Rev Biol 61:313-335

Furtana GB, Dumani H, Tipirdamaz R (2013) Seasonal changes of inorganic and organic osmolyte content in three endemic Limonium species of Lake Tuz (Turkey). Turk J Bot 37:455-463

Gagneul D, Aïnouche A, Duhazé C, Lugan R, Larher FR, Bouchereau A (2007) A. reassessment of the function of the so-called compatible solutes in the halophytic Plumbaginaceae Limonium latifolium. Plant Physiol 144:1598-1611

Gardner RC, Barchiesi S, Beltrame C, Finlayson CM, Galewski T, Harrison I, Paganini M, Perennou C, Pritchard DE, Rosenqvist A, Walpole M (2015) State of the world's wetlands and their services to people: compilation of recent analyses. Ramsar Briefing Note no. 7. Gland, Switzerland: Ramsar Convention Secretariat

Gil R, Bautista I, Boscaiu M, Lidón A, Wankahde S, Sánchez H, Llinares J, Vicente O (2014) Responses of five Mediterranean halophytes to seasonal changes in environmental conditions. AoB Plants 6 plu049. https://doi.org/10. 1093/aobpla/plu049

González-Orenga S, Ferrer-Gallego PP, Laguna E, LópezGresa MP, Donat-Torres MP, Verdeguer M, Vicente O, Boscaiu M (2019a) Insights on salt tolerance of two endemic Limonium species from Spain. Metabolites 9, 294. https://doi.org/10.3390/metabo9120294

González-Orenga S, Al Hassan M, Llinares JV, Lisón P, LópezGresa MP, Verdeguer M, Vicente O, Boscaiu M (2019b) Qualitative and quantitative differences in osmolytes accumulation and antioxidant activities in response to water deficit in four Mediterranean Limonium species. Plants 8:506. https://doi.org/10.3390/plants8110506

González-Orenga S, Llinares JV, Al Hassan M, Fita A, Collado F, Lisón P, Vicente O, Boscaiu M (2020) Physiological and morphological characterisation of Limonium species in their natural habitats: Insights into their abiotic stress responses. Plant Soil 449:267-284

Grieve CM, Poss JA, Grattam SR, Sheuse PJ, Lieth JH, Zeng L (2005) Productivity and mineral nutrition of Limonium species irrigated with saline wastewaters. Hort Sci 40:654-658

Grigore MN, Toma C (2020) Integrative anatomy of halophytes from Mediterranean Climate. In: Grigore MN. (ed) Handbook of halophytes. Springer, Cham. https://doi.org/ 10.1007/978-3-030-17854-3_40-1

Gunes A, Pilbeam DJ, Inal A, Bagci EG, Coban S (2007) Influence of silicon on antioxidant mechanisms and lipid peroxidation in chickpea (Cicer arietinum L.) cultivars under drought stress. J Plant Interact 2:105-113

Hameed A, Gulzar S, Aziz I, Hussain T, Gul B, Khan MA (2015) Effects of salinity and ascorbic acid on growth, water status and antioxidant system in a perennial halophyte. AoB Plants 7.https://doi.org/10.1093/aobpla/plv004

Hanson DA, Rathinasabapathi B, Chamberlin B, Gage DA (1991) Comparative Physiological evidence that B-alanin betaine and choline-O-sulfate act as compatible osmolytes in halophytic Limonium species. Plant Physiol 97:1199-1205

Hoagland DR, Arnon DI (1950) The water-culture method for growing plants without soil. California Agriculture Experiment Station Publications. C347 rev 1950

Hodges DM, DeLong JM, Forney CF, Prange RK (1999) Improving the thiobarbituric acid-reactive-substances assay for estimating lipid peroxidation in plant tissues containing anthocyanin and other interfering compounds. Planta 207:604-611

Iriondo JM, Albert MJ, Bañares Á, De la Cruz M, Domínguez F, Escudero A, García MB, Guzmán D, Marrero M, Moreno JC, Sainz H, Tapia F, Torres E (2003) Metodología de obtención de datos en poblaciones naturales. In: Bañares A, Blanca G, Güemes J, Moreno JC, Ortiz S (eds) Atlas y Libro Rojo de la Flora Vascular Amenazada de España. Taxones prioritarios. Ministerio de Medio Ambiente, Madrid, pp 37-40

Iriondo JM, Albert MJ, Bañares Á, De la Cruz M, Domínguez F, Escudero A, García MB, Guzmán D, Marrero M, Moreno JC, Sainz H, Tapia F, Torres E (2009) Data collection in populations. In: Iriondo JM, Albert MJ, Giménez Benavides F, Domínguez F, Escudero A (eds) Populations in peril: demographic viability of threatened Spanish vascular flora. Ministerio de Medio Ambiente. Medio Rural y Marino, Madrid, pp 19-35

Li Y (2008) Kinetics of the antioxidant response to salinity in the halophyte Limonium bicolor. Plant Soil Environ 54:493-497

Lichtenthaler HK, Wellburn AR (1983) Determinations of total carotenoids and chlorophylls a and b of leaf extracts in different solvents. Biochem Soc Trans 11:591-592

Loeppert RH, Suarez DL (1996) Carbonate and gypsum. In: Bartels JM (ed) Methods of soil analysis. Part 3. Chemical methods, Book series 5, Bigham, Wisconsin, pp 437-474

Loreto F, Velikova V (2002) Isoprene produced by leaves protects the photosynthetic apparatus against ozone damage, quenches ozone products, and reduces lipid peroxidation of cellular membranes. Plant Physiol 127:1781-1787

Martínez-Fort J, Donat-Torres MP (2020) Spartina genus in the Valencian littoral (Spain). In: Grigore MN (ed) Handbook of halophytes. From molecules to ecosystems towards biosaline agriculture. Springer (in press)

Mateo G, Crespo MB (2014) Claves ilustradas de la Flora Valenciana. Monografías de Flora Montiberica. 6. Jolube, Jaca.

Mitsch WJ, Bernal B, Hernández ME (2015) Ecosystem services of wetlands. Int J Biodivers Sci Ecosyst Serv Manag $11: 1-4$

Morales MA, Olmos E, Torrecillas A, Sánchez-Blanco MJ, Alarcó J (2001) Differences in water relations, leaf ion accumulation and excretion rates between cultivated and wild species of Limonium sp. grown in conditions of saline stress. Flora 196:345-352

Nakano Y, Asada K (1981) Hydrogen peroxide is scavenged by ascorbate specific peroxidase in spinach chloroplasts. Plant Cell Physiol 22:867-880

Navarro A, Oltra JE, Pérez Botella J, Pérez Rovira P, Laguna E (2010) Cartografía de poblaciones de táxones del Catálogo Valenciano de Especies de Flora Amenazadas. In: Giménez P, Marco JA, Matarredona E, Padilla A, Sánchez A 
(eds) Biogeografía. Una ciencia para la conservación del medio. Universidad de Alicante, Alicante, pp 99-107

Ozgur R, Uzilday B, Sekmen AH, Turkan I (2013) Reactive oxygen species regulation and antioxidant defence in halophytes. Funct Plant Biol 40:832-847

Palacios C, González-Candelas F (1997) Analysis of population genetic structure and variability using RAPD markers in the endemic and endangered Limonium dufourii (Plumbaginaceae). Mol Ecol 6:1107-1121

Palacios C, Kresovich S, González-Candelas F (1999) A population genetic study of the endangered plant speices Limonium dufourii (Plumbaginaceae) based on amplified fragment length polymorphism (AFLP). Mol Ecol 8:645-657

Rhodes D, Hanson AD (1993) Quaternary ammonium and tertiary sulfonium compounds in higher plants. Annu Rev Plant Physiol Plant Mol Biol 44:357-384

Rivas-Martínez S, Fernández-González F, Loidi J, Lousa M, Penas A (2001) Syntaxonomical checklist of vascular plant communities of Spain and Portugal to association level. Itinera Geobotanica 14:5-341

Rivas-Martínez S, Díaz TE, Fernández-González F, Izco J, Loidi J, Lousa M (2002) Vascular plant communities of Spain and Portugal. Addenda to the syntaxonomical checklist of 2001. Itinera Geobotanica 15:5-922

Ruiz-Riaguas A, Zengin G, Sinan KI, Salazar-Mendías C, Llorent-Martínez EJ (2020) Phenolic profile, antioxidant activity, and enzyme inhibitory properties of Limonium delicatulum (Girard) Kuntze and Limonium quesadense Erben. J Chem 1016208.https://doi.org/10.1155/2020/1016208

Senizza B, Zhang L, Rocchetti G, Zengin G, Ak G, Yıldıztugay E, Elbasan F, Jugreet S, Mahomoodally MF, Lucini L (2021) Metabolomic profiling and biological properties of six Limonium species: novel perspectives for nutraceutical purposes. Food Funct 12(8):3443-3454. https://doi.org/ 10.1039/d0fo02968h

SIAR. The Agroclimatic Information System for Irrigation (SIAR). SIAR (Sistema de Información Agroclimática para Regadío). Benifaió. Llíria and Moncada agro-meteorological stations. Available via http://eportal.miteco.gob.es/websiar/ Inicio.aspx. Accessed 15 May 2020 (in Spanish)

Sofo A, Scopa A, Nuzzaci M, Vitti A (2015) Ascorbate peroxidase and catalase activities and their genetic regulation in plants subjected to drought and salinity stresses. Int J Mol Sci 16:13561-13578

Soria JM (2006) Past, present and future of l'Albufera of Valencia Natural Park. Limnetica 25:135-142

Souid A, Gabriele M, Longo V, Pucci L, Bellani L, Smaoui A, Abdelly C, Hamed K (2016) Salt tolerance of the halophyte Limonium delicatulum is more associated with antioxidant enzyme activities than phenolic compounds. Funct Plant Biol 43:607-619

Souid A, Bellani L, Magné C, Zorrig W, Smaoui A, Abdelly C, Longo V, Hamed K (2018) Physiological and antioxidant responses of the sabkha biotope halophyte Limonium delicatulum to seasonal changes in environmental conditions. Plant Physiol Biochem 123:180-191

Souid A, Bellani L, Gabriele M, Pucci L, Smaoui A, Abdelly C, Hamed KB, Longo V (2019) Phytochemical and biological activities in Limonium species collected in different biotopes of Tunisia. Chem Biodivers 16:e1900216
Sutton-Grier AE, Sandifer PA (2019) Conservation of wetlands and other coastal ecosystems: a commentary on their value to protect biodiversity, reduce disaster impacts, and promote human health and well-being. Wetlands 39:1295-1302

Tabot PT, Adams JB (2014) Salt secretion, proline accumulation and increased branching confer tolerance to drought and salinity in the endemic halophyte Limonium linifolium. S Afr J Bot 94:64-73

Taulavuori E, Hellström EK, Taulavuori K, Laine K (2001) Comparison of two methods used to analyse lipid peroxidation from Vaccinium myrtillus (L.) during snow removal, reacclimation and cold acclimation. J Exp Bot 52:2375-2380

Tipirdamaz R, Gagneul D, Duhazé AA, Monnier C, Özkum D, Larher F (2006) Clustering of halophytes from an inland salt marsh in Turkey according to their ability to accumulate sodium and nitrogenous osmolytes. Environ Exp Bot 57:139-153

Touchette BW, Kneppers MK, Eggert MC (2019) Salt marsh plants: Biological overview and vulnerability to climate change. In: Hasanuzzaman M, Shabala S, Fujita M (eds) Halophytes and climate change: adaptive mechanisms and potential uses. CAB International, Wallingford, pp 115-134

van der Maarel E (1979) Transformation of cover-abundance values in phytosociology and its effects on community similarity. Vegetatio 39:97-114

Walkley A, Black IA (1934) An examination of the Degtjareff method for determining soil organic matter and a proposed modification of the chromic acid titration method. Soil Sci 37:29-38

Wang LS, Li WL, Ma L, Chen J, Lu H, Jian TY (2016) Salt stress changes chemical composition in Limonium bicolor (Bag.) Kuntze, a medicinal halophytic plant. Ind Crop Prod 84:248-253

Wang LS, Li WL, Qi XW, Ma L, Wu WL (2017) Physiological and proteomic response of Limonium bicolor to salinity. Russ J Plant Physiol 64:349-360

Weber HE, Moravec J, Theurillat JP (2000) International code of phytosociological nomenclature. J Veg Sci 11:739-768

Wolanski E, Brinson M, Cahoon DME, Perillo GME (2009) Coastal wetlands: a synthesis. In: Perillo GME, Wolanski E, Cahoon DME, Brinson MM (eds) Coastal wetlands: an integrated ecosystem approach. Elsevier, Amsterdam, pp 1-62

Worldwide Bioclimatic Classification System (1996-2020) Rivas-Martínez S, Rivas-Saenz S. Phytosociological Research Center. Spain. Available via http://www.globa lbioclimatics.org. Accessed 15 May 2020

Zhang X, Yin HB, Chen SH, He J, Guo SL (2014) Changes in antioxidant enzyme activity and transcript levels of related genes in Limonium sinense Kuntze seedlings under $\mathrm{NaCl}$ stress. J Chem 2014:749047. https://doi.org/10.1155/2014/749047

Zhishen J, Mengcheng T, Jianming W (1999) The determination of flavonoid contents in mulberry and their scavenging effects on superoxide radicals. Food Chem 64:555-559

Publisher's note Springer Nature remains neutral with regard to jurisdictional claims in published maps and institutional affiliations. 